\title{
\#USES
}

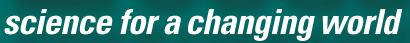

Prepared in cooperation with the City of Salem

\section{Suspended-Sediment Loads and Yields in the North Santiam River Basin, Oregon, Water Years 1999-2004}

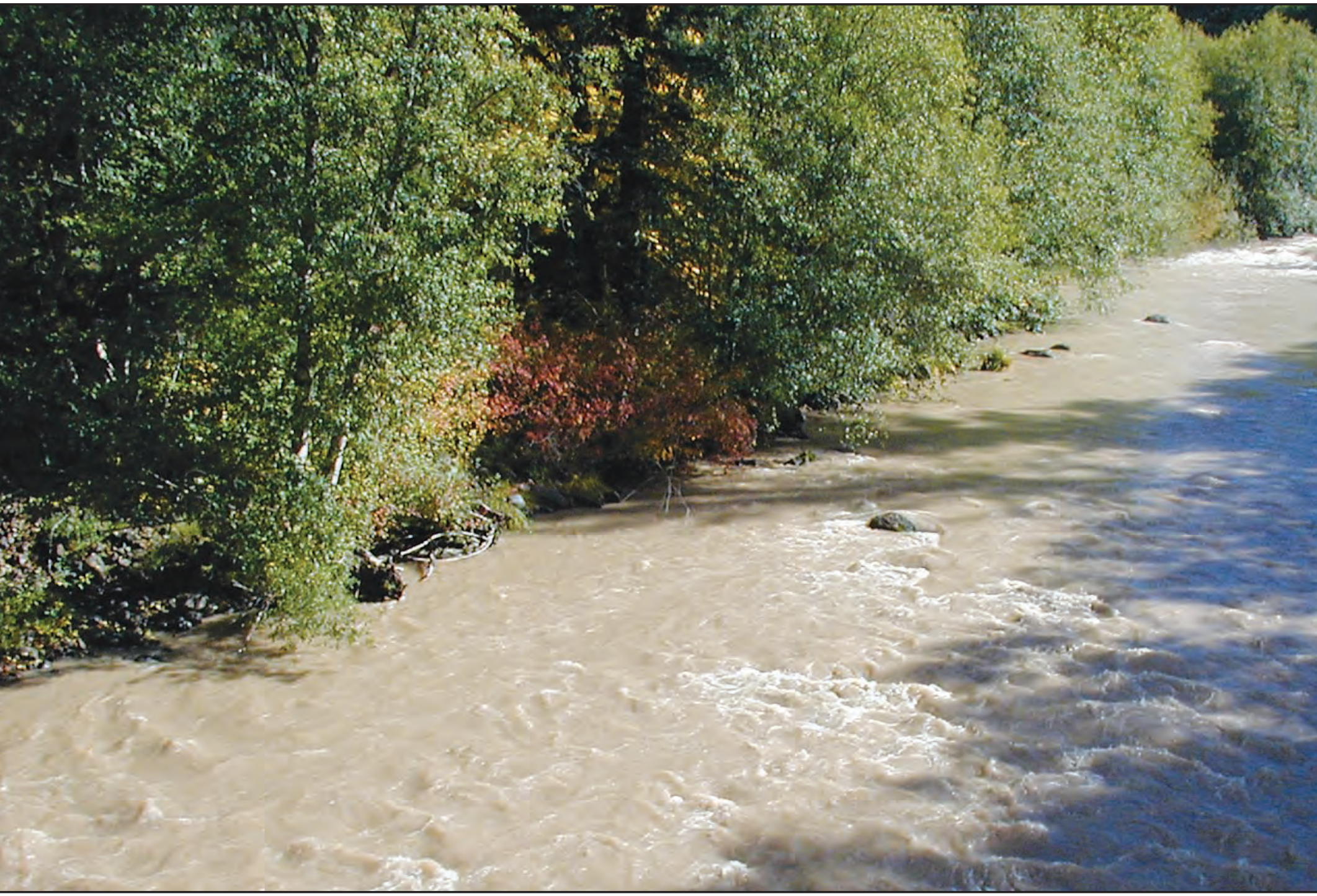

Scientific Investigations Report 2007-5187 
Cover: Photograph showing North Santiam River downstream of U.S. Geological Survey monitoring station, looking upstream from Blowout Road bridge.

(Photograph taken by Heather Bragg, U.S. Geological Survey, October 21, 2003.) 


\section{Suspended-Sediment Loads and Yields in the North Santiam River Basin, Oregon, Water Years 1999-2004}

By Heather M. Bragg, Steven Sobieszczyk, Mark A. Uhrich, and David R. Piatt

Prepared in cooperation with the City of Salem

Scientific Investigations Report 2007-5187 


\title{
U.S. Department of the Interior DIRK KEMPTHORNE, Secretary
}

\author{
U.S. Geological Survey \\ Mark D. Myers, Director
}

\section{U.S. Geological Survey, Reston, Virginia: 2007}

For product and ordering information:

World Wide Web: http://www.usgs.gov/pubprod

Telephone: 1-888-ASK-USGS

For more information on the USGS--the Federal source for science about the Earth, its natural and living resources, natural hazards, and the environment:

World Wide Web: http://www.usgs.gov

Telephone: 1-888-ASK-USGS

Any use of trade, product, or firm names is for descriptive purposes only and does not imply endorsement by the U.S. Government.

Although this report is in the public domain, permission must be secured from the individual copyright owners to reproduce any copyrighted materials contained within this report.

Suggested citation:

Bragg, H.M., Sobieszczyk, Steven., Uhrich, M.A., and Piatt, D.R., 2007, Suspended-sediment loads and yields in the North Santiam River basin, Oregon, water years 1999-2004: U.S. Geological Survey Scientific Investigations Report 2007-5187, $26 \mathrm{p}$. 


\section{Contents}

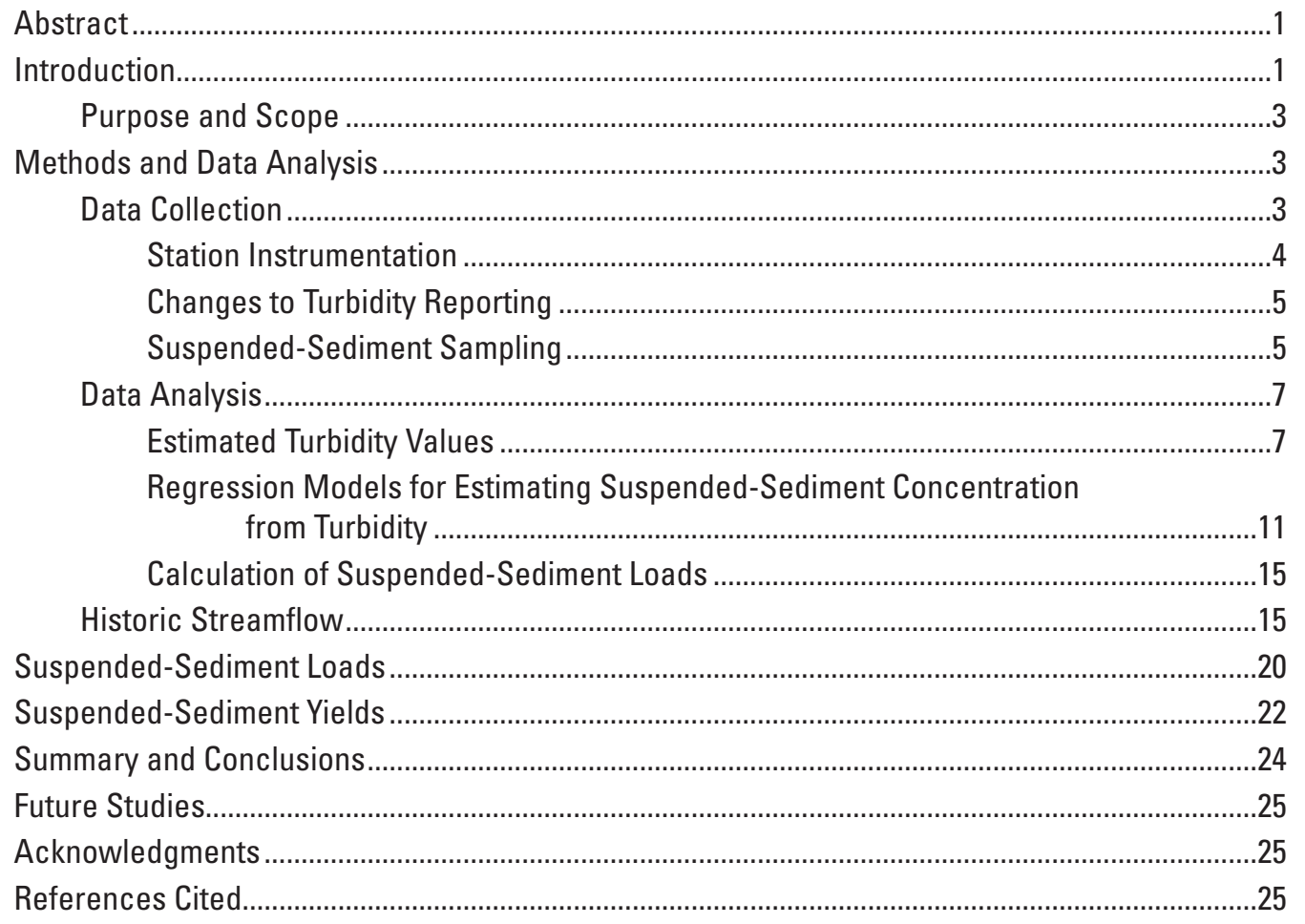




\section{Figures}

Figure 1. Map showing location of study area and water-quality monitoring stations in the North Santiam River Basin, Oregon.....

Figure 2. Photograph showing a technician collecting a suspended-sediment sample using Equal-Width Increment method from the cableway at Breitenbush River above French Creek, near Detroit in the North Santiam River basin, Oregon, January 30, 2003

Figure 3. Graph showing recorded and estimated turbidity values at North Santiam River below Boulder Creek, near Detroit, North Santiam River Basin, Oregon, October 1, 2000

Figure 4. Photograph showing North Santiam River as seen from the cableway at North Santiam River below Boulder Creek, near Detroit, North Santiam River basin, Oregon, October 21, 2003

Figure 5. Photograph showing first set (24 of 40 bottles total) of automatic pumped samples collected at North Santiam River below Boulder Creek, near Detroit, North Santiam River basin, Oregon, October 20-22, 2003

Figure 6. Graph showing recorded and estimated turbidity values at North Santiam River below Boulder Creek, near Detroit, North Santiam River basin, Oregon, October 21, 2003

Figure 7. Photographs showing debris flow and a road failure (inset) in Blowout Creek subbasin in the North Santiam River basin, Oregon, December 17, 2001

Figure 8. Graph showing recorded and estimated turbidity values at Blowout Creek near Detroit, North Santiam River Basin, Oregon, December 17, 2001

Figure 9. Graphs showing regression models for estimating suspended-sediment concentration from instream turbidity for monitoring stations in the upper and lower basins in the North Santiam River basin, Oregon

Figure 10. Graphs showing annual mean streamflow at gaging stations in the North Santiam River basin, Oregon .....

Figure 11. Graphs showing peak streamflow at gaging stations in the North Santiam River basin, Oregon

Figure 12. Graphs showing total annual and highest 3-day suspended-sediment load at monitoring stations in the North Santiam River basin, Oregon, water years 1999-2004

Figure 13. Graphs showing suspended-sediment yield at monitoring stations in the North Santiam River basin, Oregon, water years 1999-2004 23

\section{Tables}

Table 1. Streamflow-gaging and water-quality monitoring stations used to collect water-quality samples in the North Santiam River basin, Oregon

Table 2. Schedule of water-quality and suspended-sediment sample collection in the North Santiam River basin, Oregon

Table 3. Regression models used for estimating suspended-sediment concentration from turbidity for monitoring stations in the North Santiam River basin, Oregon ... 13 


\section{Conversion Factors, Datums, and Abbreviations}

Conversion Factors

\begin{tabular}{lcl}
\hline Multiply & By & To obtain \\
\hline acre-foot (acre-ft) & 1233 & cubic meter $\left(\mathrm{m}^{3}\right)$ \\
cubic foot per second $\left(\mathrm{ft}{ }^{3} / \mathrm{s}\right)$ & 0.02832 & cubic meter per second $\left(\mathrm{m}^{3} / \mathrm{s}\right)$ \\
foot (ft) & 0.3048 & meter $(\mathrm{m})$ \\
inch (in) & 25.40 & millimeter $(\mathrm{mm})$ \\
mile (mi) & 1.609 & kilometer $(\mathrm{km})$ \\
square mile $\left(\mathrm{mi}^{2}\right)$ & 2.590 & square kilometer $\left(\mathrm{km}^{2}\right)$ \\
ton (short) & 907.2 & kilogram $(\mathrm{kg})$ \\
ton per square mile (ton $\left./ \mathrm{mi}^{2}\right)$ & 0.3503 & megagram per square kilometer $\left(\mathrm{Mg} / \mathrm{km}^{2}\right)$ \\
\hline
\end{tabular}

\section{Datums}

Horizontal coordinate information is referenced to the North American Datum of 1927 (NAD 27).

Vertical coordinate information is referenced to National Geodetic Vertical Datum of 1929

(NGVD 29).

Altitude, as used in this report, refers to distance above the vertical datum.

Abbreviations

\begin{tabular}{ll}
\hline Abbreviation & Meaning \\
\hline FNU & $\begin{array}{l}\text { Formazin Nephelometric Unit } \\
\text { micrometer } \\
\mu m\end{array}$ \\
milligram per liter \\
L & liter \\
NTRU & Nephelometric Turbidity Ratio Unit \\
NTU & Nephelometric Turbidity Unit \\
& \\
EWI & equal-width increment \\
LED & light-emitting diode \\
Q & streamflow \\
SSC & suspended-sediment concentration \\
SSL & suspended-sediment load \\
SSQ & suspended-sediment discharge \\
SSY & suspended-sediment yield \\
T & turbidity \\
& \\
NWIS & National Water Information System \\
USGS & U.S. Geological Survey \\
YSI & Yellow Springs Instruments \\
\hline
\end{tabular}

Water year is the 12-month period from 0ctober 1 through September 30 and is identified by the calendar year in which it ends. For example, the period October 1, 2003, through September 30, 2004 , is designated the 2004 water year. 
This page intentionally left blank. 


\title{
Suspended-Sediment Loads and Yields in the North Santiam River Basin, Oregon, Water Years 1999-2004
}

\author{
By Heather M. Bragg, Steven Sobieszczyk, Mark A. Uhrich, and David R. Piatt
}

\section{Abstract}

The North Santiam River provides drinking water to the residents and businesses of the city of Salem, Oregon, and many surrounding communities. Since 1998, water-quality data, including turbidity, were collected continuously at monitoring stations throughout the basin as part of the North Santiam River Basin Turbidity and Suspended Sediment Study. In addition, sediment samples have been collected over a range of turbidity and streamflow values. Regression models were developed between the instream turbidity and suspended-sediment concentration from the samples collected from each monitoring station. The models were then used to estimate the daily and annual suspended-sediment loads and yields. For water years 1999-2004, suspended-sediment loads and yields were estimated for each station. Annual suspendedsediment loads and yields were highest during water years 1999 and 2000. A drought during water year 2001 resulted in the lowest suspended-sediment loads and yields for all monitoring stations. High-turbidity events that were unrelated or disproportional to increased streamflow occurred at several of the monitoring stations during the period of study. These events highlight the advantage of estimating suspendedsediment loads and yields from instream turbidity rather than from streamflow alone.

\section{Introduction}

The North Santiam River drains $778 \mathrm{mi}^{2}$ of land from its headwaters in the Cascade Range to its confluence with the South Santiam River 12 mi south of Salem, Oregon (fig. 1). The altitude of the North Santiam River basin ranges from nearly $10,500 \mathrm{ft}$ at the Mount Jefferson summit to $460 \mathrm{ft}$ at the Willamette Valley floor. Like other Western Cascade rivers, the North Santiam River originates in the mountains as glacial runoff, snowmelt, and ground-water outflow. As the river runs its course, tributaries such as Boulder Creek, Rock Creek, and the Little North Santiam River flow into the mainstem.
The North Santiam River is regulated by two dams, both constructed in 1953 by the U.S. Army Corps of Engineers. Detroit Dam is the larger of the two and farther upstream, and has a drainage area of $437 \mathrm{mi}^{2}$. Detroit Dam impounds Detroit Lake, providing flood control, pollution abatement, power generation, irrigation, and recreation. Water-surface altitudes on Detroit Lake vary by season and hydrologic conditions. The maximum pool altitude is $1,574 \mathrm{ft}$, full pool is $1,569 \mathrm{ft}$, and minimum conservation pool is 1,425 ft (U.S. Army Corps of Engineers, 1953). Storage capacity for Detroit Lake ranges from 455,000 acre-ft in the summer to 115,000 acre- $\mathrm{ft}$ in the winter. Big Cliff Dam is 3 mi downstream of Detroit Dam. The water-surface altitude of Big Cliff Lake ranges from 1,210 to $1,180 \mathrm{ft}$ as it regulates water releases from Detroit Dam.

The North Santiam River basin is prone to occasionally severe erosion resulting from steep slopes, a dense network of tributaries, and periods of intense rainfall. Notably, a storm front with unusually mild temperatures and humid air moved through the region during February 1996, resulting in 12 -15 in. of rainfall in 4 days (Oregon Climate Service, 2005). The intense rainfall, coupled with rapidly melting snowpack, caused peak streamflows with recurrence intervals of 50-100 years at many streamflow-gaging stations (Cooper, 2005). The flooding triggered Federal disaster declarations for all affected counties. Because the North Santiam River supplies drinking water for the city of Salem and neighboring communities, the turbid flood water caused numerous financial problems. The city of Salem's Geren Island water-treatment facility closed for 8 days because of its inability to process the sediment-rich water. Costs for this closure and other storm-related problems totaled \$1.1 million to the water utility (Hulse and others, 2002).

The financial burden and environmental consequences of the 1996 flooding prompted the city of Salem to coordinate with State and Federal agencies, including the U.S. Geological Survey (USGS), to establish a water-quality monitoring network (fig. 1). The North Santiam River Turbidity and Suspended-Sediment Study was initiated in 1998 to investigate the sources and transport of sediment causing high turbidity. 


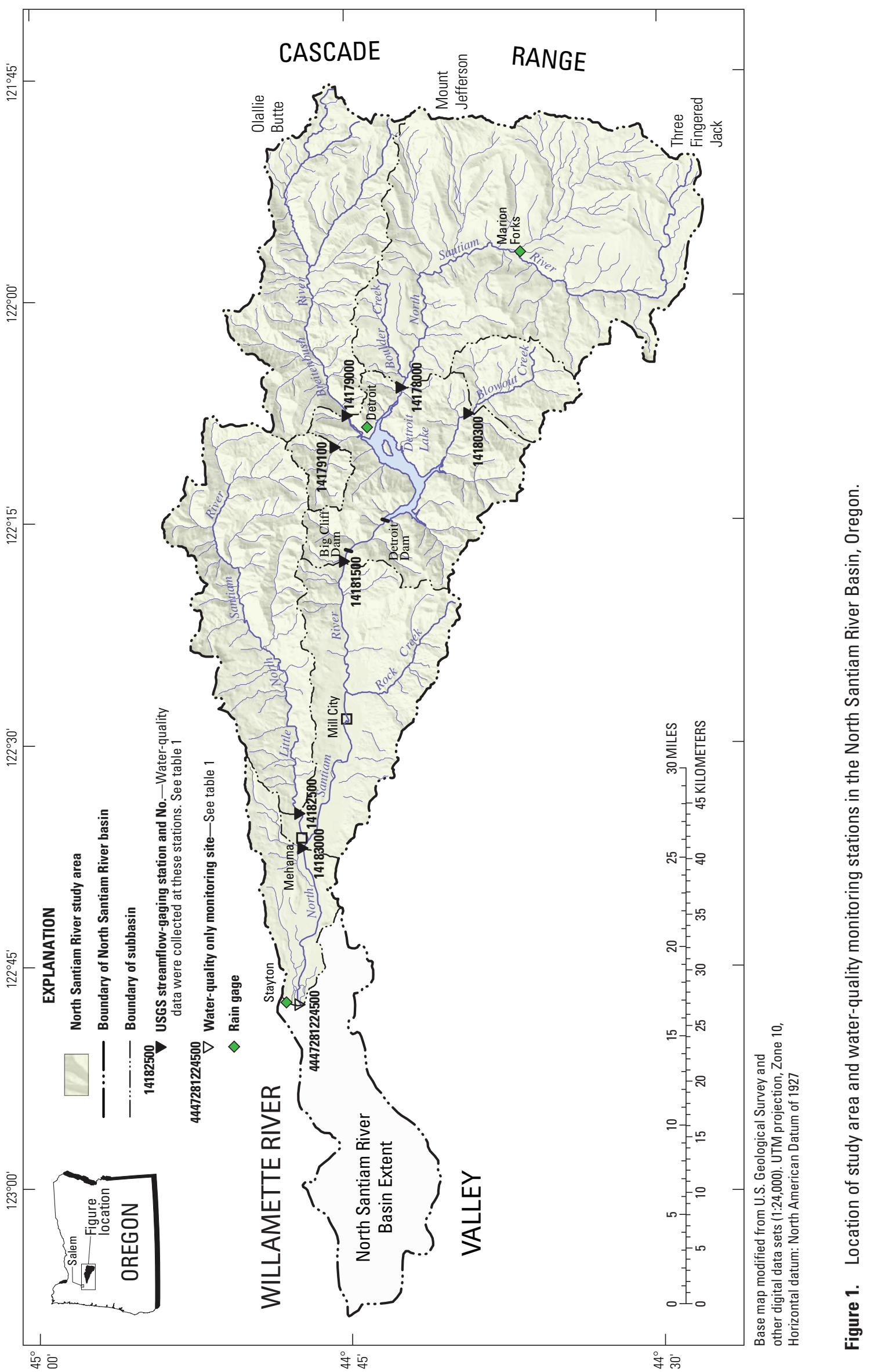


Uhrich and Bragg (2003) detailed the first 2 years of monitoring in the North Santiam River basin, from October 1998 to September 2000. The report included streamflow and water-quality data for three monitoring stations in the upper basin (upstream of Detroit Dam) and established a technique for estimating suspended-sediment loads. Since September 2000, five additional stations have been added to the monitoring network, including four stations in the lower basin (downstream of Detroit Dam). The ongoing water-quality monitoring and additional research are jointly funded by the city of Salem and the USGS.

\section{Purpose and Scope}

This report provides additional data to update and expand the analysis presented in the previous report (Uhrich and Bragg, 2003). The regression models relating turbidity and suspended-sediment concentration for the three existing upperbasin monitoring stations are refined by inclusion of additional data. Regression models for turbidity and suspended-sediment concentrations also have been established for four additional monitoring stations. Annual suspended-sediment loads and yields for water years 1999-2004, when both streamflow and turbidity data are available, are estimated for the seven monitoring stations. The streamflow data for several long-term gaging stations are analyzed to provide historical context for the high-flow and high-turbidity events. The highest turbidity events are then identified and discussed in relation to the annual suspended-sediment loads.

\section{Methods and Data Analysis}

\section{Data Collection}

At the time of the February 1996 flooding, the USGS managed four streamflow-gaging stations in the North Santiam River basin (North Santiam, Niagara, Little North, and M ehama; table 1). The gaging station at Breitenbush had been discontinued in 1987 but was reestablished in water year 1999 at the start of this study. Two additional monitoring stations (French and Blowout) were established in the upper basin, providing both streamflow and water-quality data for the study. Streamflow data were not collected at G eren Island. Standard USGS methods were applied to data collected at each gaging station to assure the quality of the streamflow record (U.S. Geological Survey, 2000-2005).

Table 1. Streamflow-gaging and water-quality monitoring stations in the North Santiam River basin, Oregon.

[Locations of streamflow-gaging stations are shown in figure 1. Abbreviations: mi $^{2}$, square mile; N/A, not applicable]

\begin{tabular}{|c|c|c|c|c|c|}
\hline \multirow[b]{2}{*}{$\begin{array}{c}\text { USGS } \\
\text { station No. }\end{array}$} & \multirow[b]{2}{*}{ Station name } & \multirow[b]{2}{*}{ Station reference } & \multirow{2}{*}{$\begin{array}{c}\text { Drainage } \\
\text { basin area } \\
\left(\mathrm{mi}^{2}\right)\end{array}$} & \multicolumn{2}{|c|}{ Streamflow-gaging station } \\
\hline & & & & $\begin{array}{c}\text { Period of } \\
\text { record } \\
\text { (water year) }\end{array}$ & $\begin{array}{l}\text { Years of } \\
\text { record }\end{array}$ \\
\hline \multicolumn{6}{|c|}{ Upper basin stations } \\
\hline 14178000 & $\begin{array}{l}\text { North Santiam River below } \\
\text { Boulder Creek, near Detroit }\end{array}$ & North Santiam & 216 & $\begin{array}{l}\text { 1908-1909, } \\
1929-2004\end{array}$ & 78 \\
\hline 14179000 & $\begin{array}{l}\text { Breitenbush River above French } \\
\text { Creek, near Detroit }\end{array}$ & Breitenbush & 108 & $\begin{array}{l}\text { 1933-1987, } \\
1999-2004\end{array}$ & 61 \\
\hline 14179100 & French Creek near Detroit & French & 10 & 2002-2004 & 3 \\
\hline 14180300 & Blowout Creek near Detroit & Blowout & 26 & 1999-2004 & 6 \\
\hline \multicolumn{6}{|c|}{ Lower basin stations } \\
\hline 14181500 & North Santiam River at Niagara & Niagara & 453 & $\begin{array}{l}\text { 1909-1920, } \\
1922, \\
1939-2004\end{array}$ & 79 \\
\hline 14182500 & $\begin{array}{l}\text { Little North Santiam River near } \\
\text { Mehama }\end{array}$ & Little North & 112 & 1932-2004 & 73 \\
\hline 14183000 & North Santiam River at Mehama & M ehama & 655 & $\begin{array}{l}1905-07,1911 \\
1921-2004\end{array}$ & 91 \\
\hline 4447281224500 & $\begin{array}{l}\text { North Santiam River at Geren } \\
\text { Island, near Stayton }\end{array}$ & Geren Island & 688 & N/A & N/A \\
\hline
\end{tabular}


All preliminary streamflow and water-quality data are available in near real time on the USGS North Santiam River study website (http://or.water.usgs.gov/santiam/). These data, as well as suspended-sediment analyses, are available through the USGS National Water Information System (NWIS) website (http://waterdata.usgs.gov/or/nwis).

The amount of precipitation within the North Santiam River basin varies locally on the basis of many factors, including geography and altitude. The amount of rain associated with each storm is given as the range of measured precipitation for several Oregon Climate Service (2005) rain gages in the basin. The Marion Forks gage is located the farthest east and at the highest altitude, the Detroit Dam gage is centrally located, and the Stayton gage is the farthest west and at the lowest altitude (fig. 1). Data from these three raingaging sites allow the magnitudes of the significant storms to be compared.

\section{Station Instrumentation}

Between 1998 and 2001, water-quality instruments were installed at eight stations, either in conjunction with existing streamflow-gaging stations or at new sites. In October 1998, three water-quality monitoring stations (North Santiam, Breitenbush, and Blowout) were established in the upper basin on the major tributaries of Detroit Lake. In April 2000, waterquality instruments were installed at existing streamflowgaging stations in the lower basin (Niagara, Little North, and M ehama). In June 2001, a water-quality and streamflowgaging station was established at French, and in March 2002, a water-quality-only monitoring site was established at Geren I sland (table 2). Each of the eight water-quality monitoring stations included a Yellow Springs Instruments (YSI) multiparameter water-quality instrument. The instruments were outfitted with water temperature, specific conductance, $\mathrm{pH}$, and turbidity sensors. Routine field checks, calibrations,

Table 2. Schedule of water-quality and suspended-sediment sample collection in the North Santiam River basin, Oregon.

[Station reference: Complete station names are shown in table 1. Abbreviations: EWI, equal-width increment. N/A, not applicable]

\begin{tabular}{|c|c|c|c|c|c|}
\hline \multirow{2}{*}{ Station reference } & \multirow{2}{*}{$\begin{array}{c}\text { Water-quality } \\
\text { instrumentation } \\
\text { installation dates }\end{array}$} & \multirow{2}{*}{$\begin{array}{l}\text { Sample- } \\
\text { collection } \\
\text { dates }\end{array}$} & \multicolumn{3}{|c|}{ Type and number of suspended-sediment sample } \\
\hline & & & EWI & Dip & Total \\
\hline \multicolumn{6}{|c|}{ Upper basin stations } \\
\hline North Santiam & October 1998 & $\begin{array}{l}\text { October } 1998- \\
\text { September } 2004\end{array}$ & 106 & 15 & 121 \\
\hline Breitenbush & October 1998 & $\begin{array}{l}\text { October } 1998- \\
\text { September } 2004\end{array}$ & 67 & 13 & 80 \\
\hline French & June 2001 & $\begin{array}{l}\text { June 2001- } \\
\text { September } 2004\end{array}$ & 24 & 10 & 34 \\
\hline Blowout & October 1998 & $\begin{array}{l}\text { October } 1998- \\
\text { September } 2004\end{array}$ & 106 & 12 & 118 \\
\hline \multicolumn{6}{|c|}{ Lower basin stations } \\
\hline Niagara & April 2000 & $\begin{array}{l}\text { October } 1998- \\
\text { September } 2004\end{array}$ & 52 & 12 & 64 \\
\hline Little North & April 2000 & $\begin{array}{l}\text { October } 1998- \\
\text { September } 2004\end{array}$ & 102 & 23 & 125 \\
\hline Mehama & April 2000 & $\begin{array}{l}\text { October } 1998- \\
\text { September } 2004\end{array}$ & 111 & 20 & 131 \\
\hline Geren Island & March 2001 & N/A & N/A & N/A & N/A \\
\hline
\end{tabular}


and maintenance were performed on the YSI instruments. The results of these field checks and other USGS quality-assurance procedures sometimes indicated necessary corrections to the preliminary water-quality data (Wagner and others, 2006). All data parameters, including streamflow, were recorded semihourly (every 30 minutes) and uploaded six to eight times per day to the USGS database.

\section{Changes to Turbidity Reporting}

The variability of turbidity between sensors prompted the USGS to clarify the appropriate measurement unit corresponding to each type of turbidity sensor. Prior to October 1, 2004, most standard turbidity measurements in the United States, regardless of the sensor's light source or detector geometry, were reported in Nephelometric Turbidity Units (NTU). The common unit of turbidity measurement in Europe was the Formazin Nephelometric Unit (FNU) as defined by method ISO 7027 (International Organization for Standardization, 1999). Beginning October 1, 2004, the USGS differentiated the turbidity measurements of different instruments on the basis of the wavelength of light used and the angle at which the light is emitted and detected (Anderson, 2004). Turbidity sensors using a light-emitting diode (LED) with a wavelength of $840 \pm 60$ nanometers, and the detector at an angle of $90 \pm 2.5$ degrees to the incident light beam are now defined as measuring in Formazin Nephelometric Units. Sensors with tungsten lamps that detect scattered light at an angle of $90 \pm 30$ degrees to the incident light beam measure in NTU (U.S. Environmental Protection Agency, 1999). Most turbidity units are not directly interchangeable; therefore, it is important to document which instrument and associated measurements are used when reporting or analyzing turbidity data.

The YSI Model 6026 turbidity sensor was consistently used to monitor instream turbidity during the North Santiam River study. This sensor measures turbidity with an LED at 90 degrees. Prior to October 1, 2004, these data were reported in Nephelometric Turbidity Units. In accordance with the new USGS protocol, turbidity data from the same instrument are now reported in Formazin Nephelometric Units. All previously published turbidity data for the North Santiam study also were changed from Nephelometric Turbidity Units to Formazin Nephelometric Units in the USGS database. No conversion was needed between these data because the turbidity sensors and data analysis methods remained the same.

A Hach $2100 \mathrm{~N}$ turbidimeter also consistently was used in the laboratory during the North Santiam study. Prior to October 1, 2004, these data also were reported in Nephelometric Turbidity Units. The Hach instrument measures turbidity with a tungsten light source and has multiple detectors. The angle between these multiple detectors determines the ratio used in calculating the final turbidity readings, reported in Nephelometric Turbidity Ratio Units (NTRU).

\section{Suspended-Sediment Sampling}

In addition to instream water-quality data, suspendedsediment samples were collected at each of the monitoring stations (excluding Geren Island) over a range of hydrologic conditions. Samples were collected by hand or by automatic sampler. All samples were analyzed at the USGS Cascades Volcano Observatory sediment laboratory in Vancouver, Washington. Standard processing included suspendedsediment concentrations (SSC), reported in milligrams per liter $(\mathrm{mg} / \mathrm{L})$, and the fraction of sample sediment smaller than sand-sized particles, reported in percent finer than $62 \mu \mathrm{m}$. If sufficient sediment was available from the sample, additional analysis was performed to determine complete grain-size distribution.

During the period of study, an average of nearly 100 suspended-sediment samples was collected at each of the monitoring stations (table 2). The Equal Width Increment (EWI) method was used to collect most samples (fig. 2; Edwards and Glysson, 1999). Depth-integrated transits were made with the sampler at approximately 10 equal increments over the cross section. All water collected was composited into a single 3-liter (L) bottle for sample analysis. When streamflow conditions or safety concerns did not allow for EWI sampling, dip samples were collected. A weighted 1-L bottle was dipped at equal increments over the cross section, and the sample was composited into a single 3-L bottle.

In addition to the cross-sectional EWI and dip samples, single-point pumped samples were collected at three stations in the upper basin. A pumping sampler was installed at North Santiam in March 2003, and the samplers were installed at B reitenbush and Blowout in August 2004. The pumping samplers were positioned near the water-quality instruments and were programmed to collect samples on the basis of instream turbidity. When turbidity readings exceeded a programmed threshold value (20 FNU, for example), a 1-L sample was collected every 120 minutes. If turbidity surpassed a second and third threshold value (50 and $100 \mathrm{FNU}$, for example), samples were collected more frequently (every 60 and 30 minutes, respectively). After turbidity peaked and the values decreased, samples were collected less frequently until turbidity decreased to the lowest threshold value. The turbidity threshold values were regularly adjusted according to the time of year and the expected magnitude of storms. 


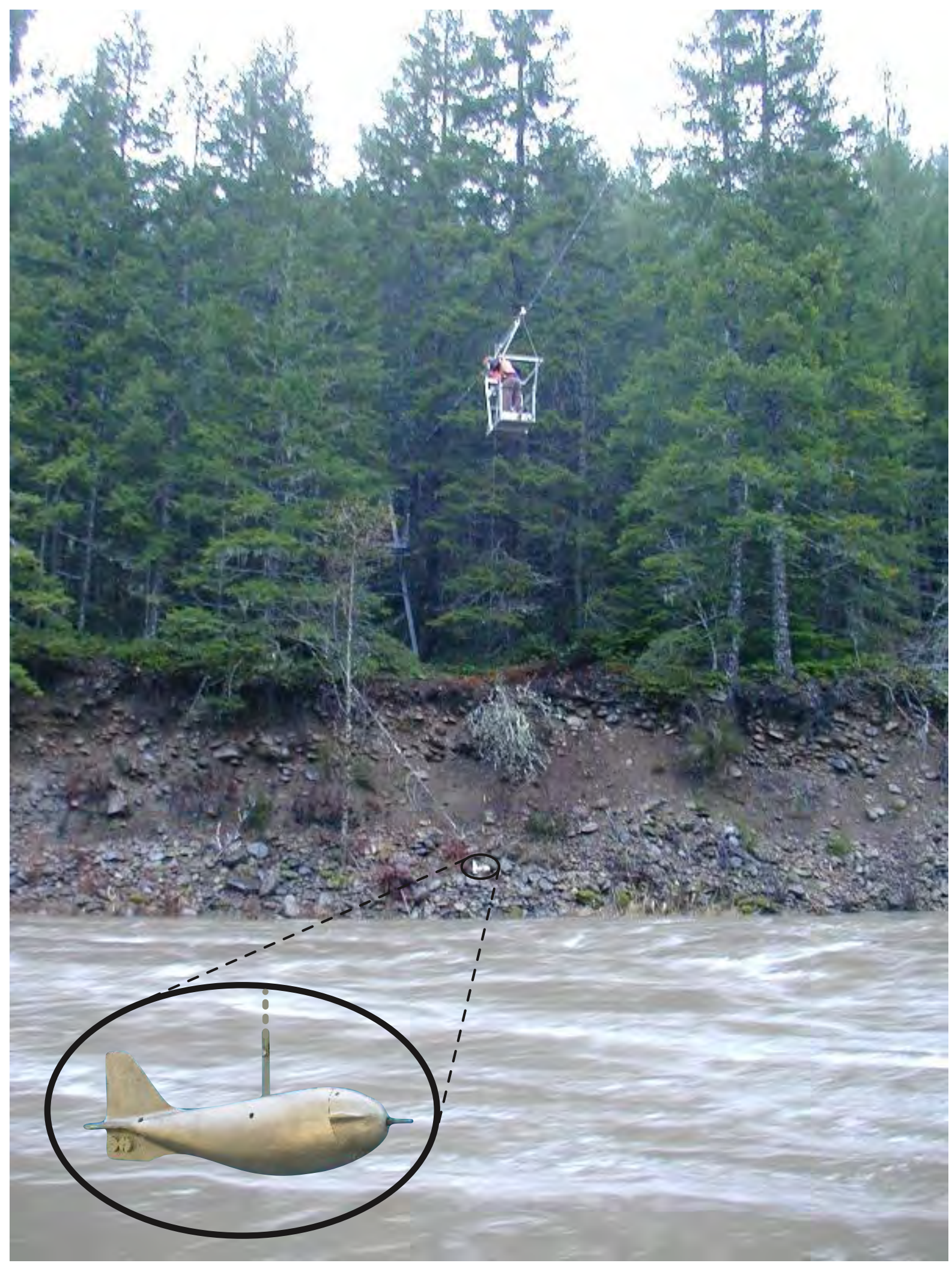

Figure 2. A technician collecting a suspended-sediment sample using Equal-Width Increment method from the cableway at Breitenbush River above French Creek, near Detroit in the North Santiam River basin, Oregon, January 30 , 2003. (Streamflow $=4,960$ cubic feet per second; turbidity $=130$ Formazin Nephelometric Units). 


\section{Data Analysis}

One objective of collecting the continuous water-quality data and suspended-sediment samples was the estimation of suspended-sediment concentration (SSC) and calculation of the suspended-sediment loads (SSL) transported past each of the monitoring stations. Historically, streamflow data were used to estimate SSC. Uhrich and Bragg (2003) demonstrated that instream turbidity could be used as a better surrogate for SSC in the North Santiam River basin. Regression models for each monitoring station were developed to estimate SSC from instream turbidity. The regression equations were used with the continuous turbidity and streamflow records to calculate daily and annual SSL values.

\section{Estimated Turbidity Values}

Instream turbidity may be missing or deleted from the data record for many reasons. Erroneous values can be recorded as a result of environmental conditions, sensor malfunction, or power interruption. On several occasions throughout the period of water-quality record, turbidity exceeded the maximum range of a sensor, resulting in the flattening of the turbidity curve during peak values. For the purposes of calculating SSL at the North Santiam River basin monitoring stations, all missing and erroneous turbidity values were estimated.

Turbidity was estimated by direct interpolation for most of the missing and deleted values. The difference between the last recorded data value prior to the malfunction and the first recorded data value following the malfunction was equally distributed over the duration of the missing record. The turbidity values at adjacent monitoring stations were compared to these estimated values for the same period of record to discount the possibility of substantially higher or lower turbidity.
In several instances, the turbidity at a monitoring station exceeded the sensor maximum. Each YSI 6026 turbidity sensor has a unique maximum value ranging from approximately 1,200 to $1,800 \mathrm{FNU}$. Turbidity data with more than two consecutive semi-hourly readings at the sensor maximum were assumed to be less than the actual instream value and were estimated. The estimation technique used for each of these events is discussed in the following sections.

North Santiam - October 1, 2000

On October 1, 2000, an event originating on the slopes of Mount Jefferson resulted in increased turbidity at North Santiam. The maximum value of the turbidity sensor was recorded for $2 \frac{1}{2}$ hours (five semi-hourly readings). With no additional data available to estimate these erroneous values, a simple extrapolation was used (fig. 3).

Two linear extrapolations were applied to the turbidity data. The line formed by the two recorded turbidity readings prior to the maximum sensor value was extrapolated forward in time. The line formed by the two recorded turbidity readings following the maximum sensor value was extrapolated backward in time until these two lines crossed. The values along these two lines corresponding to the data logging times were used as the estimated turbidity readings. The maximum estimated turbidity value (nearest to the intersection of the two extrapolated lines) for this high-turbidity event was 3,520 FNU (fig. 3). On the basis of other short-duration, high-turbidity events at North Santiam, this approach provides a reasonable, but likely conservative, estimation of the peak turbidity. 


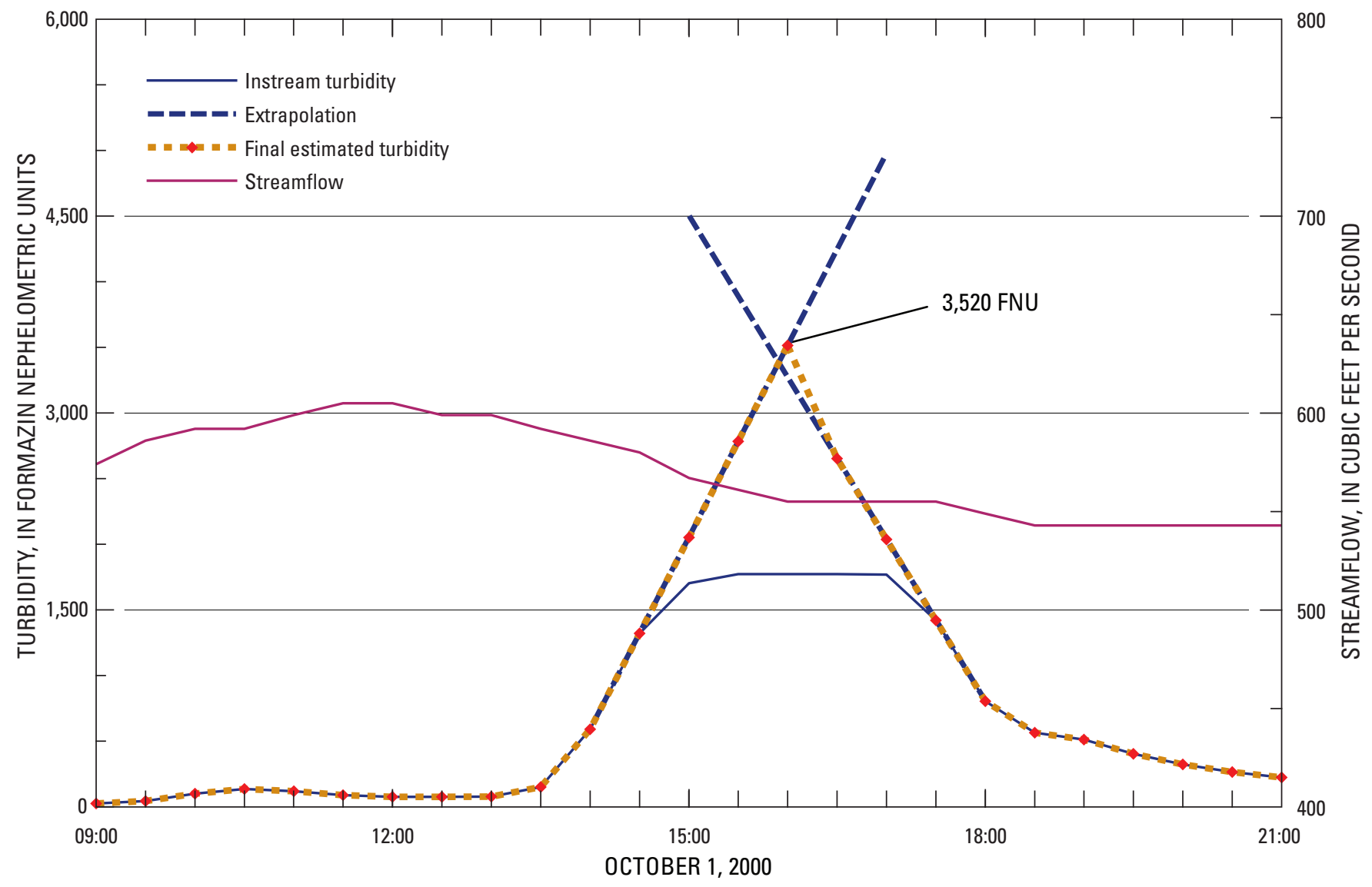

Figure 3. Recorded and estimated turbidity values at North Santiam River below Boulder Creek, near Detroit, North Santiam River Basin, Oregon, October 1, 2000.

\section{North Santiam - October 21, 2003}

In October 2003, another event occurred in the upper North Santiam Basin that resulted in increased turbidity at North Santiam (fig. 4). The turbidity increased quickly and the sensor maximum was recorded for $4 \frac{1}{2}$ hours (nine semi-hourly values). Unlike the previous example, additional data were available for estimating the peak turbidity during this event.

Forty-two samples were collected during October 20-22, 2003 at North Santiam. The pumping sampler installed at the station was programmed to collect samples for turbidity greater than 20 FNU. Beginning October 20, 2003, at 23:00 PDT, 40 pumped samples were collected during the next 30 hours (fig. 5). Two EWI samples also were collected on October 21, 2003, following the turbidity peak. All samples were analyzed with the Hach $2100 \mathrm{~N}$ turbidimeter in the laboratory. Each sample then had two associated turbidity values, measured in different units (one from the instream instrument, in Formazin Nephelometric Units, and one from the laboratory instrument, in Nephelometric Turbidity Ratio Units). A regression was developed between the two sets of turbidity data for 33 samples (the 9 pumped samples collected while the instream instrument recorded the sensor maximum were excluded). With the regression equation, the laboratory (NTRU) turbidity was used to estimate the instream (FNU) turbidity of the nine excluded pumped samples. These turbidity values were then used as the estimated instream values during the $4 \frac{1}{2} 2$ hours that the turbidity at the monitoring station recorded the sensor maximum. With this method, the maximum estimated turbidity for this event was 5,550 FNU (fig. 6).

For comparison, the extrapolation method used for the October 2000 event at North Santiam also was attempted for the October 2003 event. The resulting maximum turbidity was 3,040 FNU (fig. 6). As expected, the extrapolation method underestimated peak turbidity values above the sensor maximum for this example. This conclusion is consistent with measured data during numerous high-turbidity events in the North Santiam River basin. Turbidity data typically have steep, increasing slopes on the rising arm of the data curve rather than the constant slopes used for the extrapolation method. 


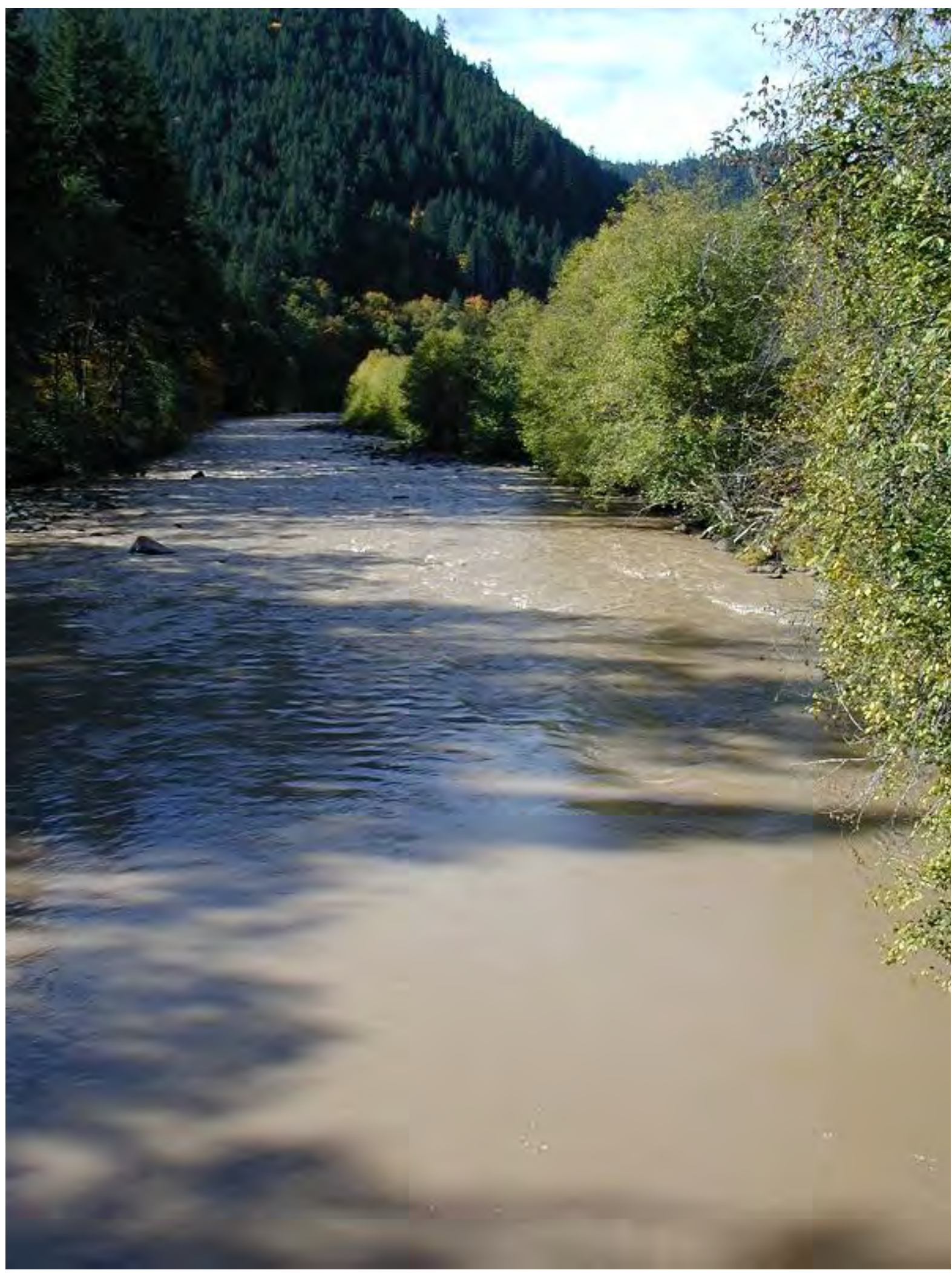

Figure 4. North Santiam River as seen from the cableway at North Santiam River below Boulder Creek, near Detroit, North Santiam River basin, Oregon, October 21, 2003. (Streamflow = 395 cubic feet per second; turbidity = 563 Formazin Nephelometric Units). 


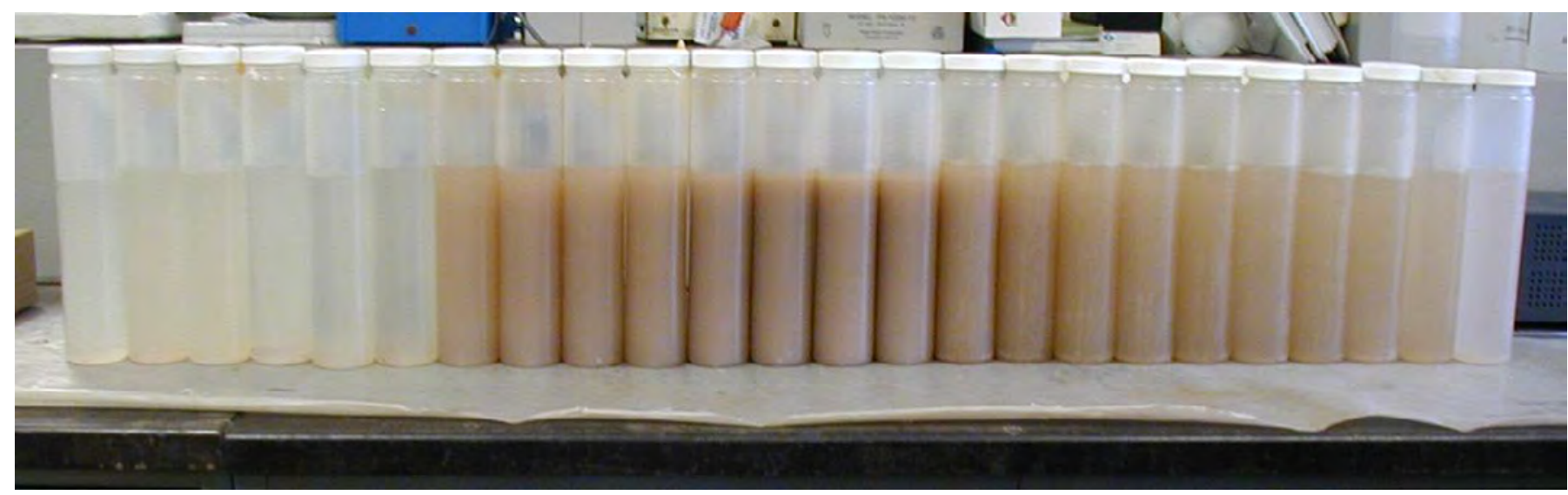

Figure 5. First set (24 of 40 bottles total) of automatic pumped samples collected at North Santiam River below Boulder Creek, near Detroit, North Santiam River basin, Oregon, October 20-22, 2003.

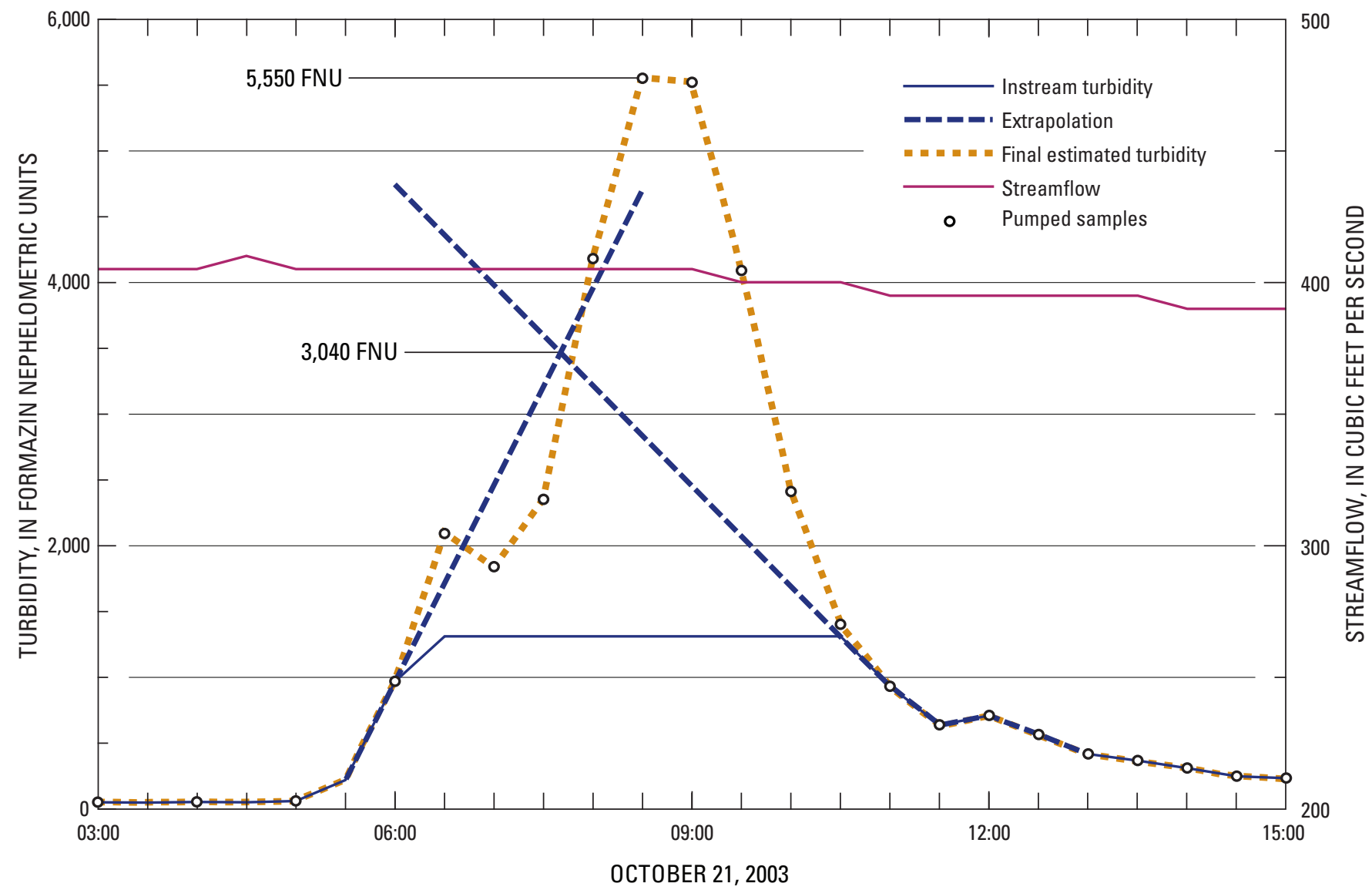

Figure 6. Recorded and estimated turbidity values at North Santiam River below Boulder Creek, near Detroit, North Santiam River basin, Oregon, October 21, 2003. 
Blowout - December 17, 2001

On December 17, 2001, debris flow and a road failure occurred in the Blowout Creek subbasin (fig. 7). At 09:30 PST, the instream turbidity at Blowout was $24 \mathrm{FNU}$. Thirty minutes later, the turbidity was 1,370 FNU, the maximum value for this sensor. The turbidity was at the sensor maximum for $2 \frac{1}{2}$ hours (5 semihourly values). With no additional data available to estimate the instream turbidity above the sensor maximum, a modified extrapolation was used.

The sediment that caused the high turbidity was entrained so quickly that the sensor reached the maximum value before a slope was defined on the rising arm of the turbidity curve. Rather than extrapolating two lines until they intersect, a single extrapolation line was used. The line formed by the two recorded turbidity readings following the maximum sensor value was extrapolated backward in time. The values along the line corresponding to the semi-hourly recorded data times were used as the estimated turbidity. The maximum estimated turbidity (the point corresponding to 10:30 PST) was 3,400 FNU (fig. 8). The rising arm of the turbidity curve was estimated with this maximum estimated turbidity and the turbidity reading immediately prior to the sensor reaching its maximum value. This extrapolation method likely underestimates the turbidity for such high-turbidity events yet provides a reasonable estimate.

\section{Regression Models for Estimating Suspended- Sediment Concentration from Turbidity}

The water-quality data and suspended-sediment samples collected at each monitoring station provided the data needed to develop regression models between instream turbidity and SSC. A detailed description of the regression techniques was presented in the previous North Santiam Basin report by Uhrich and Bragg (2003). A summary of these techniques follows.

An instream turbidity value, in Formazin Nephelometric Units, associated with each suspended-sediment sample was produced by averaging two or three recorded values over the duration of the sample collection time. An SSC value, in milligrams per liter, was provided by the laboratory analysis of the sample. For all samples collected at a monitoring station, the paired turbidity and SSC data were compiled and transformed to base-10 logarithmic values. These log values were then used to calculate a linear least-squares regression model. The model was converted to the power equation form:

$$
\text { SSC }=a \times(\text { turbidity })^{b},
$$

where $a$ and $b$ were the coefficients obtained by the regression analysis. Transformation of the turbidity and SSC data to log values and back to original form introduced a bias into the regression model. The bias was corrected with a "smearing" estimator described by Helsel and Hirsch (1992). The bias correction factor was calculated as the mean of the residual errors from the regression. The final regression model, including the correction factor, had the form:

$$
\text { SSC }=c f \times a \times(\text { turbidity })^{b}=A \times(\text { turbidity })^{b},
$$

where A was the product of the correction factor (cf) and the coefficient (a) determined by the regression analysis.

The final forms of the regression models for each monitoring station are shown in table 3 . The regression models for the seven monitoring stations are plotted in figure 9. For each station, the solid line indicates the estimated SSC that is defined by sample turbidity values used in the regression models. The dashed portion of each line indicates the range of estimated SSC and instream turbidity values at which no suspended-sediment samples were collected.

The regression models for North Santiam, B reitenbush, and Blowout differ from those used to calculate SSC for water years 1999 and 2000 in the previous report by Uhrich and Bragg (2003). Many additional samples were collected at these stations, including some with instream turbidity values greater than $100 \mathrm{FNU}$. Changes in the USGS rounding protocol for turbidity data also necessitated the exclusion of many samples with low turbidity values (less than 1 FNU) that had been included in the previous models. The removal of these samples from the analyses at North Santiam, B reitenbush, and Blowout resulted in slightly lower $\mathrm{R}^{2}$ values for the regression models at all three stations. However, the inclusion of more high-turbidity samples in the analyses improved the models for estimating SSC from high instream turbidity, when most sediment is transported. 


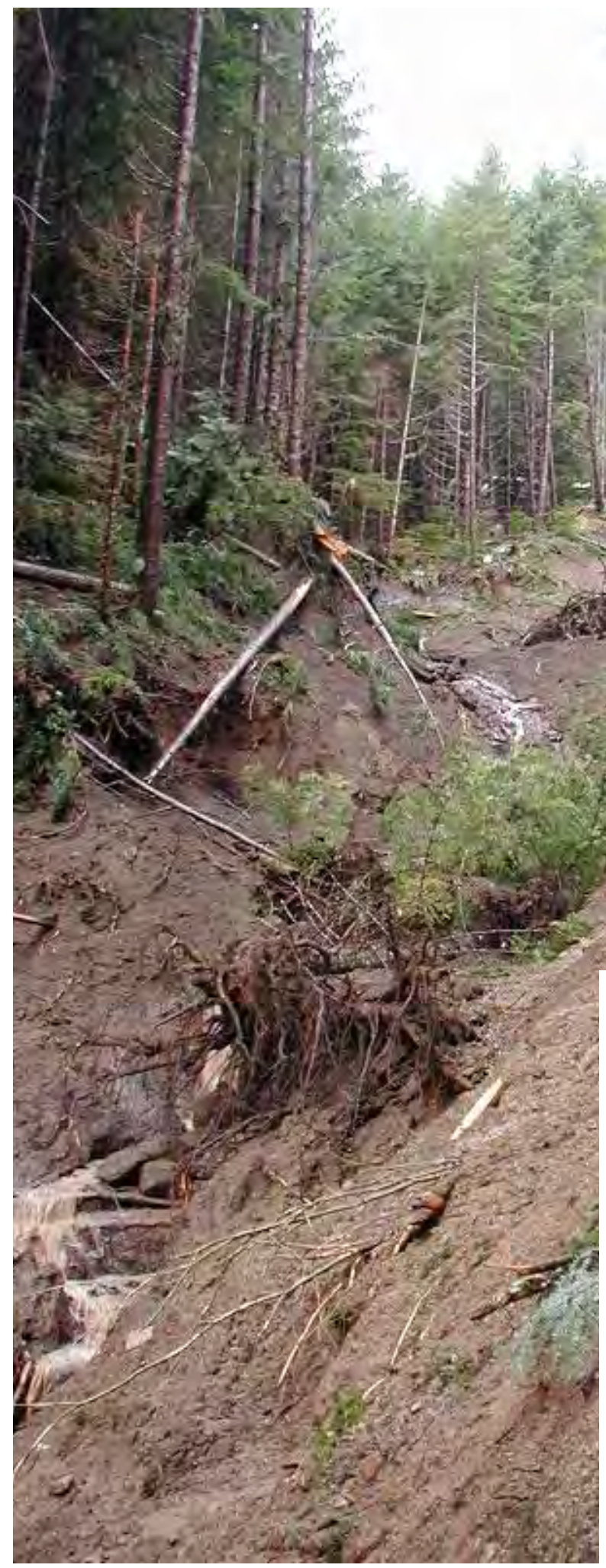

A. Debris flow
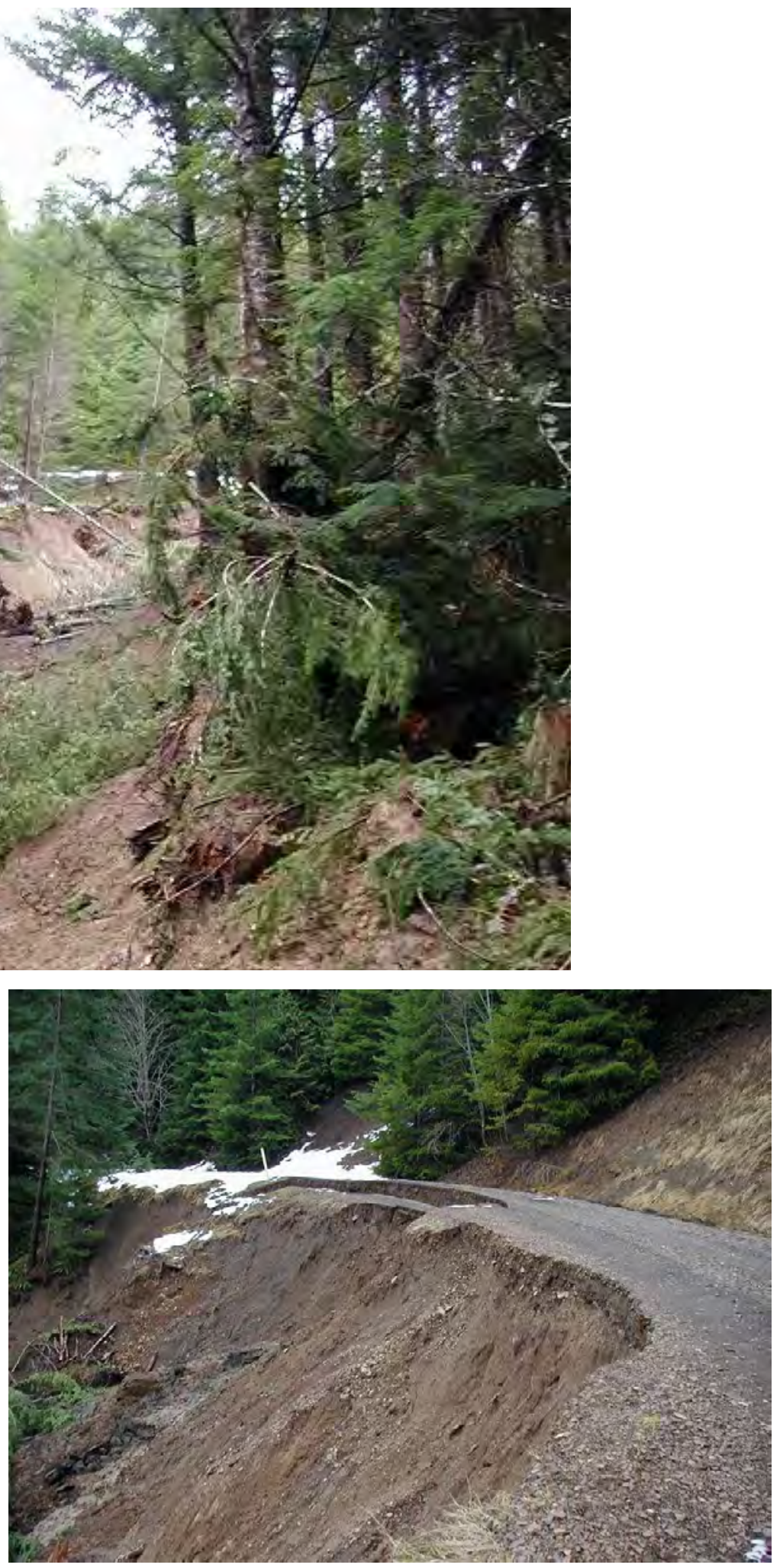

B. Road failure

Figure 7. Debris flow and a road failure (inset) in Blowout Creek subbasin in the North Santiam River basin, Oregon, December 17, 2001. 


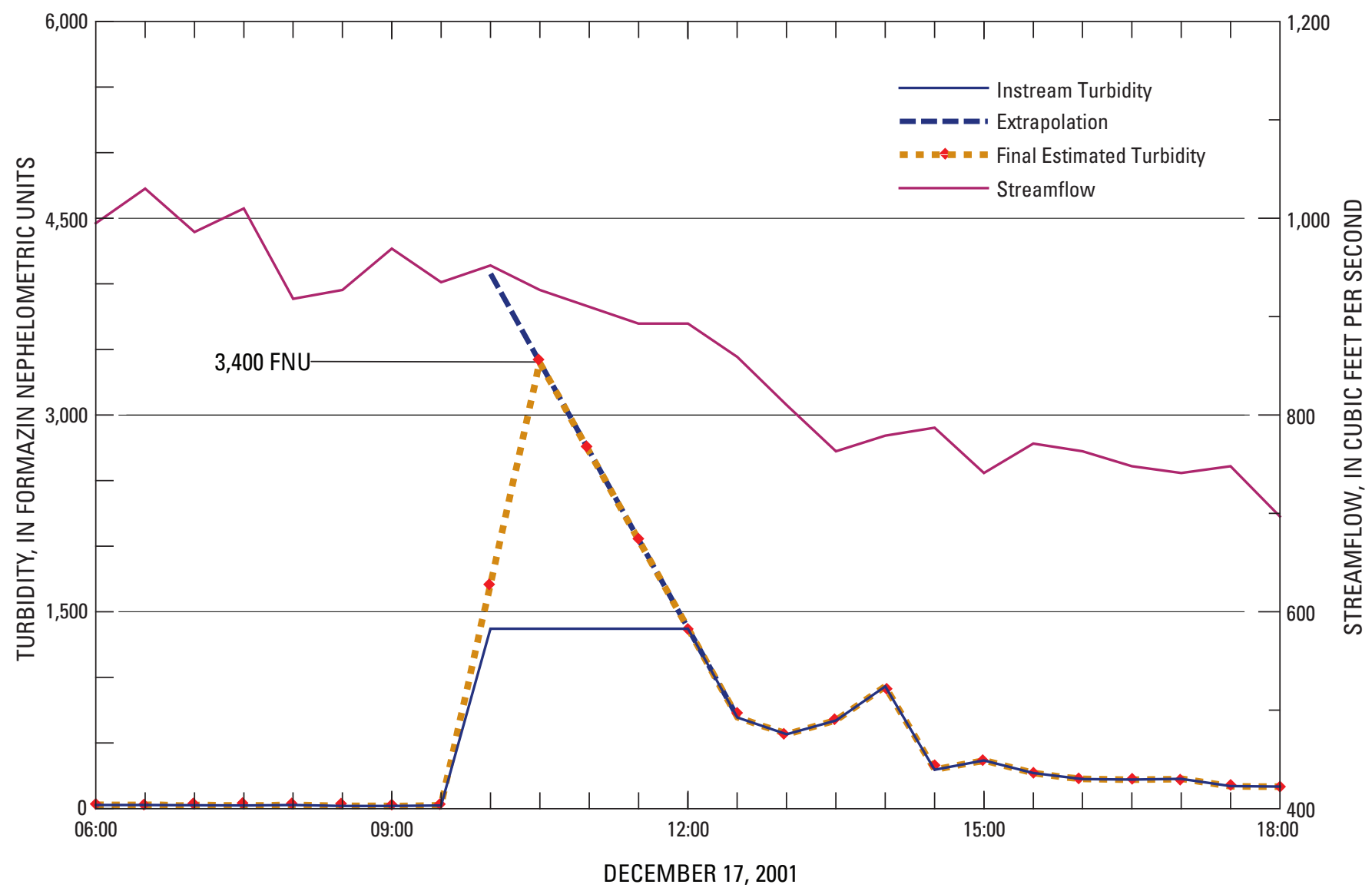

Figure 8. Recorded and estimated turbidity values at Blowout Creek near Detroit, North Santiam River Basin, Oregon, December 17, 2001.

Table 3. Regression models used for estimating suspendedsediment concentration from turbidity for monitoring stations in the North Santiam River basin, Oregon.

[Station reference: Complete station names are shown in table 1.

SSC, suspended-sediment concentration; T, turbidity]

\begin{tabular}{llc}
\hline \multicolumn{1}{c}{ Station reference } & Regression equation & $R^{2}$ value \\
\hline North Santiam & $\mathrm{SSC}=1.75 \times \mathrm{T}^{1.04}$ & 0.893 \\
Breitenbush & $\mathrm{SSC}=1.80 \times \mathrm{T}^{1.08}$ & .915 \\
French & $\mathrm{SSC}=1.25 \times \mathrm{T}^{1.01}$ & .824 \\
Blowout & $\mathrm{SSC}=1.35 \times \mathrm{T}^{1.18}$ & .928 \\
Niagara & $\mathrm{SSC}=1.49 \times \mathrm{T}^{0.758}$ & .760 \\
Little North & $\mathrm{SSC}=1.78 \times \mathrm{T}^{1.02}$ & .915 \\
M ehama & $\mathrm{SSC}=1.73 \times \mathrm{T}^{0.916}$ & .861 \\
\hline
\end{tabular}




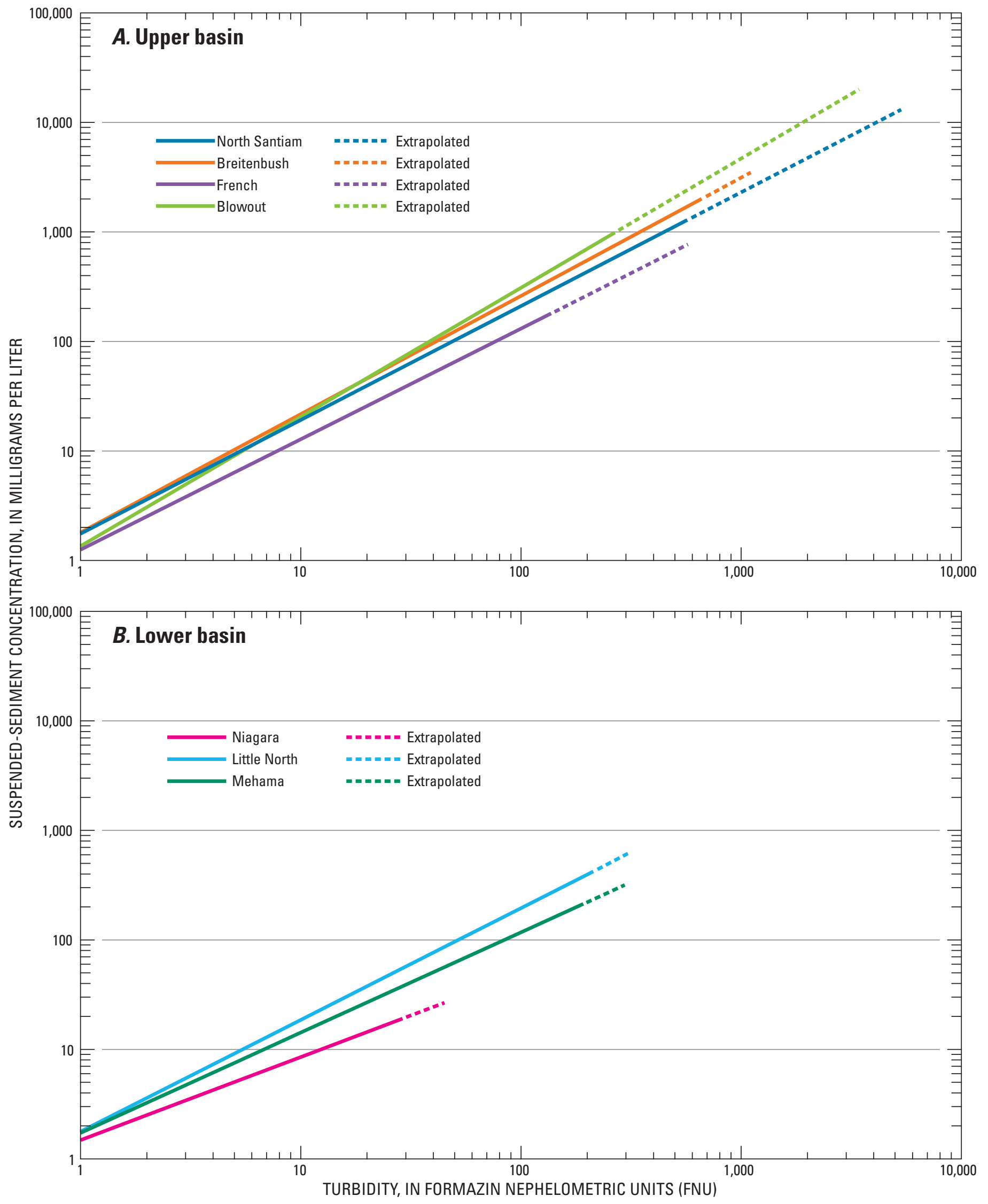

Figure 9. Regression models for estimating suspended-sediment concentration from instream turbidity for monitoring stations in the upper and lower basins in the North Santiam River basin, Oregon. 


\section{Calculation of Suspended-Sediment Loads}

Daily and annual suspended-sediment loads were calculated from the continuous turbidity and streamflow records. The regression model for each monitoring station was used to estimate suspended-sediment concentration from each semi-hourly turbidity value. The semi-hourly suspendedsediment discharge (SSQ) was calculated from the estimated SSC and the instantaneous streamflow (Q) using the following equation:

$$
\mathrm{SSQ}(\text { tons } / 30 \mathrm{~min})=\mathrm{SSC}(\mathrm{mg} / \mathrm{L}) \times Q\left(\mathrm{ft}^{3} / \mathrm{s}\right) \times c,
$$

where $C=0.0000562$, converting the units to tons per 30 minutes. The 48 semi-hourly SSQ values calculated per day were summed to estimate the daily SSL, in tons. The 365 (or 366) daily SSL values per year were then summed to provide the annual SSL for each station for each water year.

\section{Historic Streamflow}

Streamflow data from several gaging stations in the North Santiam River basin were analyzed to provide historical context for the annual mean and maximum instantaneous streamflow for water years 1999-2004 (U.S. Geological Survey, 2000-2005). Five of the water-quality stations were installed at long-term USGS streamflow-gaging stations (North Santiam, B reitenbush, Niagara, Little North, and M ehama; fig. 1). The gaging stations at North Santiam and
Breitenbush are located in the upper basin (upstream of Detroit Lake) where streamflow is not affected by operation of the two dams. Niagara and M ehama are both on the mainstem North Santiam River downstream of the dams. M ehama is located nearly 20 mi downstream of Big Cliff Dam with many tributaries (including that gaged at Little North) contributing to the streamflow. Niagara is located less than 1 mi downstream of Big Cliff Dam where streamflow is highly regulated and not responsive to natural flow conditions. Niagara therefore was not included in the historical streamflow analysis.

The streamflow extremes took place during the first 3 years of the 6-year period of study. Annual mean streamflows were highest during water year 1999, when flows at N orth Santiam, Breitenbush, and M ehama were greater than the $75^{\text {th }}$ percentile (fig. 10). However, the storm producing the peak streamflows occurred in water year 2000. In November 1999 , peak flows were greater than the $75^{\text {th }}$ percentile at North Santiam, B reitenbush, and M ehama for their respective periods of record and the peak flow at Little North was greater than the $95^{\text {th }}$ percentile (fig. 11). Streamflows were lowest during water year 2001, when the region experienced a severe drought. The 2001 annual mean streamflows for North Santiam, Breitenbush, Little North, and M ehama were less than the $5^{\text {th }}$ percentile (fig. 10). The peak flows for all four stations also were less than the $5^{\text {th }}$ percentile (fig. 11).

Annual mean and peak streamflows during water years 2002-04 were less extreme than those during water years 1999-2001. Mean annual and peak streamflows generally fell between the $25^{\text {th }}$ and $75^{\text {th }}$ percentiles for all stations during water years 2002-04. 


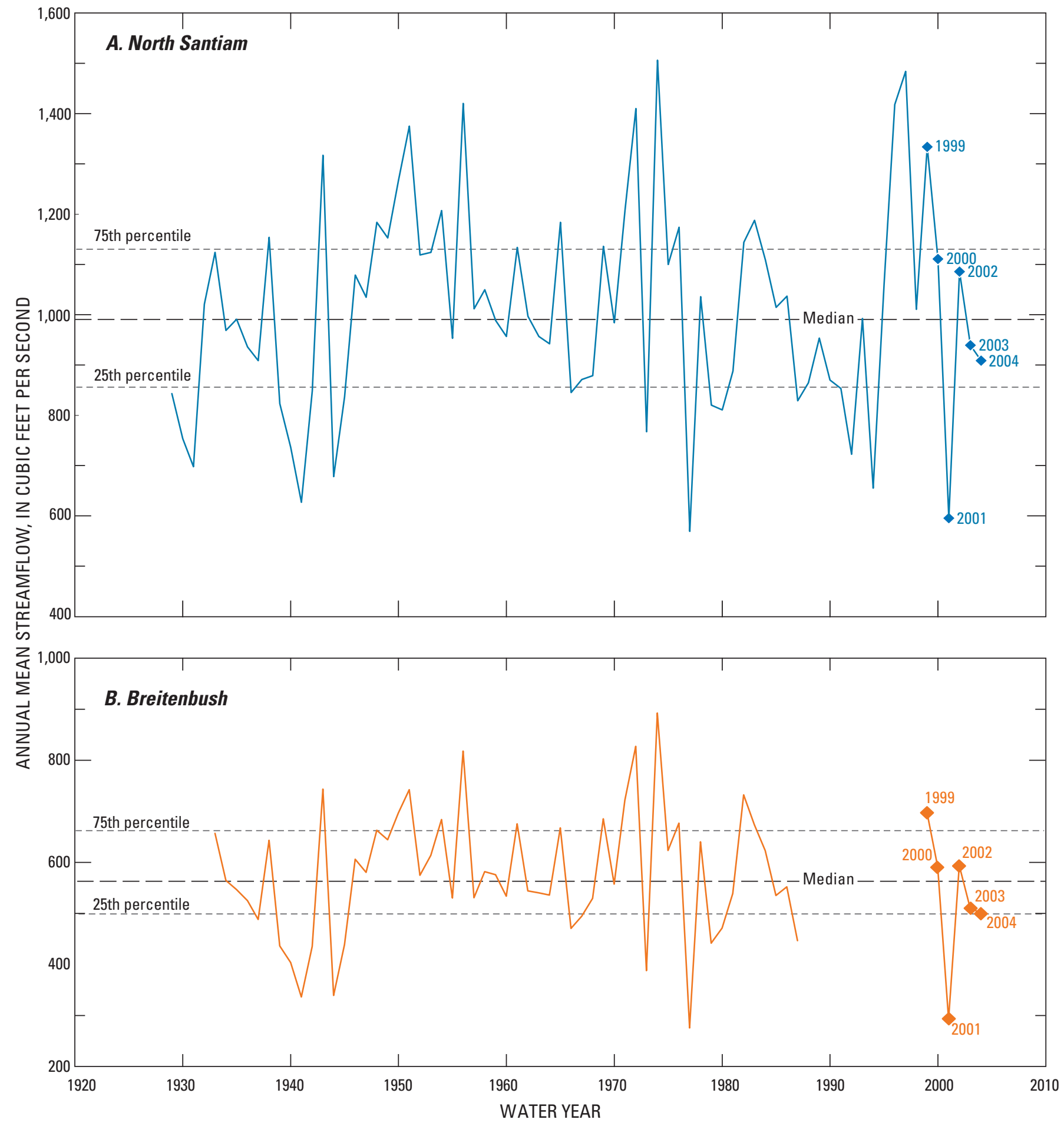

Figure 10. Annual mean streamflow at gaging stations in the North Santiam River basin, Oregon. Station reference is defined in table 1. 


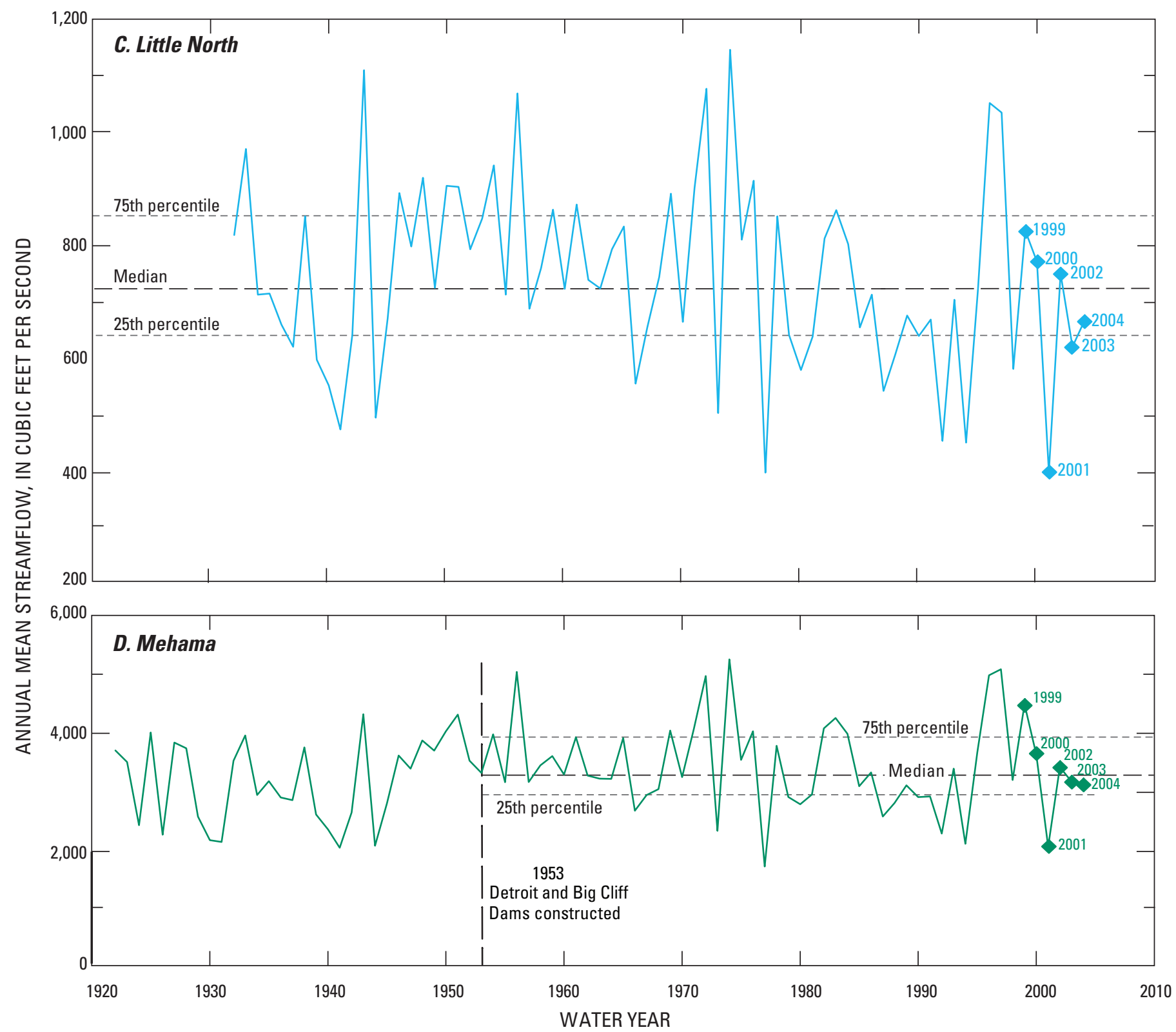

Figure 10.-Continued. 


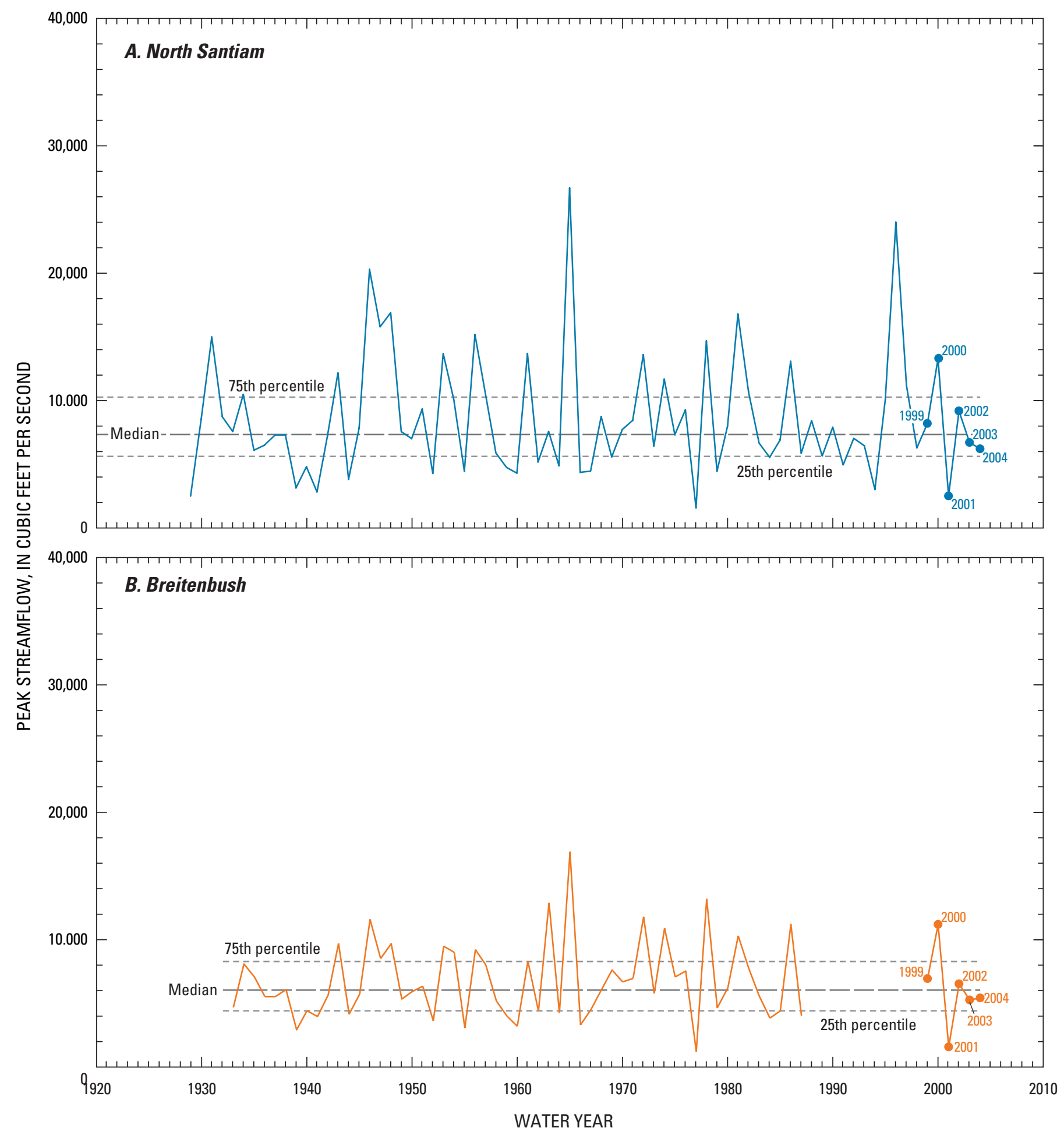

Figure 11. Peak streamflow at gaging stations in the North Santiam River basin, Oregon. Station reference is defined in table 1. 


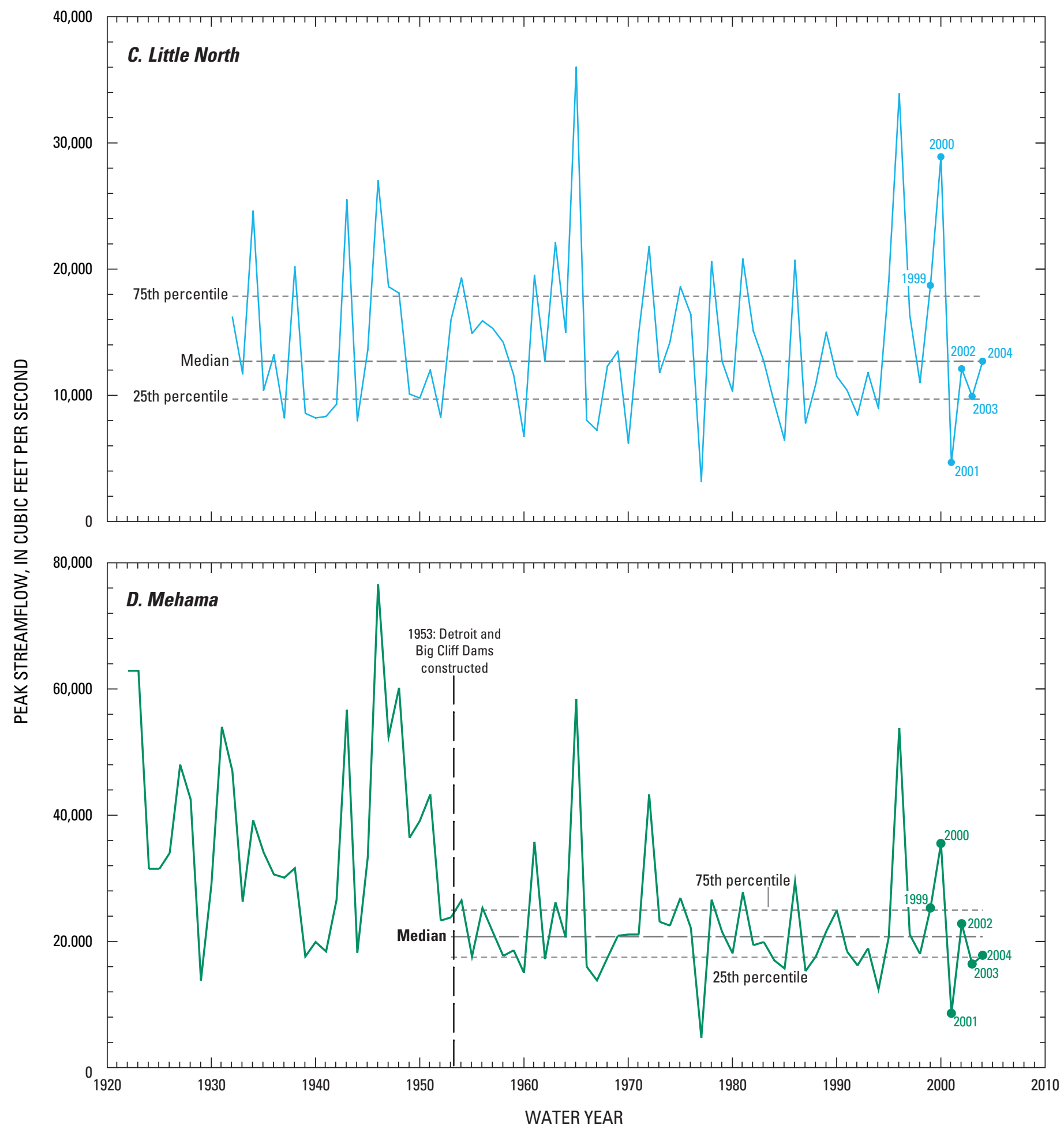

Figure 11.-Continued. 


\section{Suspended-Sediment Loads}

The effects of the varied hydrologic conditions from year to year were reflected in the SSL estimates. On the basis of the streamflow analysis, annual SSL was highest during water years 1999 and 2000 and lowest during water year 2001 for most of the monitoring stations (fig. 12). In addition to the annual SSL, the highest consecutive 3-day SSL was calculated to demonstrate the effect of a single short-term event at each station for each water year.

SSL was calculated at the monitoring stations only when both turbidity and streamflow data were available. Therefore, SSL was not estimated for the lower-basin stations (Niagara, Little N orth, and M ehama) for water years 1999-2000 or for F rench for water years 1999-2001. Water-quality instruments had not yet been installed at these stations, and turbidity data were not available.

\section{Water Year 1999}

Total SSL was substantial during water year 1999. Blowout had its highest annual SSL and both North Santiam and Breitenbush had their second highest SSL for the period of study. Annual mean streamflow data indicated that water year 1999 was the highest annual streamflow year for water years 1999-2004. The highest 3-day SSL occurred during December 27-29, 1998, when the basin received 7-8 in. of rain (Oregon Climate Service, 2005). Peak streamflow during this storm was classified as a $2-5$ year recurrence flood at several of the gaging stations (Cooper, 2005). The 14,100 tons of sediment transported past Blowout during the December storm were more than double the 3-day SSL at that station for any of the other water years (fig. 12).

\section{Water Year 2000}

SSL was highest during water year 2000 for the period of study at both North Santiam and B reitenbush. Although the annual streamflows were lower than in water year 1999, the maximum instantaneous flows were much higher at the three upper-basin gaging stations. Seven to 10 in. of rain fell in the basin during November 25-27, 1999, resulting in the largest precipitation-driven event for the period of study (Oregon Climate Service, 2005). The resulting 10-25-year recurrence interval flood produced the highest streamflow and SSL for the water year (fig. 12; Cooper, 2005). The 22,200 tons at North Santiam was the highest 3-day SSL at the station for water years 1999-2004. The greatest SSL at any of the monitoring stations for the entire period of study occurred at B reitenbush during this storm. An estimated 69,800 tons of sediment was transported past the station in 3 days.

\section{Water Year 2001}

Water year 2001 was a severe drought year. The highest SSL and streamflow occurred at different times during the winter and spring in conjunction with storms producing less than 4 in. of rain over 3 days (Oregon Climate Service, 2005). Annual mean flows and the peak streamflows were less than the $5^{\text {th }}$ percentile for the four gaging stations for which data was analyzed. The highest SSL recorded at Blow out was during December 22-24, 2000, and at Breitenbush during April 30-May 2, 2001. The highest SSL at North Santiam was not related to either of these storms. As discussed in section, "Data Analysis," an event in the upper North Santiam River subbasin on October 1, 2000, caused extremely turbid water at the monitoring station. The resulting 1,700 tons of sediment was the highest 3-day SSL for any of the stations for the water year. SSL was first estimated at the lower-basin monitoring stations for water year 2001. The highest SSL at Niagara occurred December 23-25, 2000 (following the highest SSL at Blowout). The highest SSL values at Little North and M ehama were recorded during the storm on April 30-May 2, 2001. The annual SSL values for all six monitoring stations were the lowest for each during the 6 years of study (fig. 12).

\section{Water Year 2002}

A spring storm produced the highest SSL totals for water year 2002. The highest 3-day SSL for three of the upper-basin stations (N orth Santiam, B reitenbush, and F rench) occurred during April 13-15, 2002, when 2 to 3 in. of rain fell in 3 days (Oregon Climate Service, 2005). Little N orth and M ehama also had their highest SSL during this storm. The annual SSL of 35,200 tons at M ehama was the highest for the period of study (fig. 12). The peak streamflows at the gaging stations were near average (between $25^{\text {th }}$ and $75^{\text {th }}$ percentile) for all stations during this storm. Blowout recorded increased SSL during the April storm, but its highest SSL occurred during December 17-19, 2001. As discussed in section, "Data Analysis," debris flow and a road failure in the Blowout Creek subbasin produced increased turbidity and SSL at the station. The maximum SSL values at Niagara occurred during December 21-23, 2001, and April 14-16, 2002, in the days following high SSL values in the upper basin. 

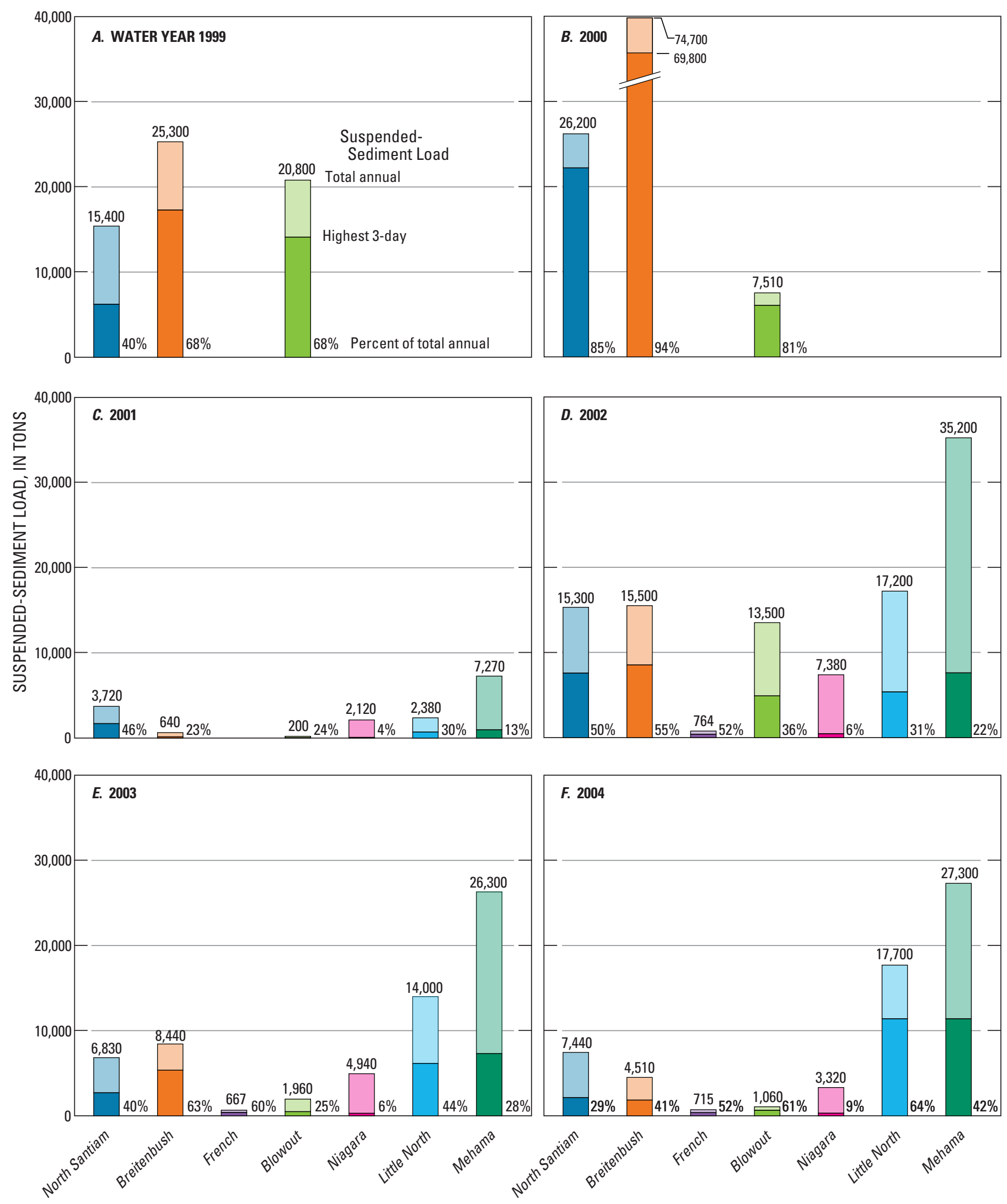

Figure 12. Total annual and highest 3-day suspended-sediment load at monitoring stations in the North Santiam River basin, Oregon, water years 1999-2004. 
Water Year 2003

During water year 2003, several storms produced increased SSL totals for the North Santiam monitoring stations. The highest SSL values for most of the upper-basin stations occurred January 30-February 1, 2003, during a storm that generated 5-7 in. of rain in 3 days (Oregon Climate Service, 2005). This storm also resulted in the highest 3-day SSL totals at Little North and M ehama (fig. 12). The peak streamflow analysis indicates that the storm was considered average for three of the four gaging stations. The JanuaryFebruary storm resulted in increased SSL at Blowout, but the highest SSL at the station occurred during March 21-23, 2003. Niagara had its highest SSL values following both the January and March storms.

\section{Water Year 2004}

Annual mean and maximum instantaneous streamflows for water year 2004 were below-average for most of the North Santiam River basin monitoring stations. As in October 2000 (and discussed in section "Data Analysis"), the highest SSL at North Santiam resulted from an event originating high in the subbasin. For the other upper-basin stations, one of two storms produced the highest 3-day SSL. The first storm occurred December 13-15, 2003, with 4-5 in. of rain in 3 days (Oregon Climate Service, 2005). The highest 3-day SSL values at $B$ reitenbush and Blowout were recorded during this storm. The next storm occurred during January 28-30, 2004, and generated 3-5 in. of rain in 3 days (Oregon Climate Service, 2005). This storm produced the highest SSL at French. The three lower-basin stations also recorded their highest 3-day SSL in relation to the January storm.

\section{Suspended-Sediment Yields}

Suspended-sediment yields (SSY) were calculated by dividing the estimated annual suspended-sediment loads (SSL) by the area, in square miles, of each subbasin. Normalizing the annual SSL by the respective subbasin areas provides additional context for the events discussed in section, "Suspended-Sediment Loads."

The peak storms of water years 1999 and 2000 demonstrate the effect that a small subbasin, such as that upstream from Blow out $\left(26 \mathrm{mi}^{2}\right)$, can have on sediment production in the North Santiam River basin. Although the highest SSL for water year 1999 was recorded at Breitenbush, the SSL at Blowout resulted in three times the sediment per unit area (fig. 13). The estimated 800 tons $/ \mathrm{mi}^{2}$ was the highest SSY for any of the stations for any of the water years during the study. The Breitenbush River produced the highest SSY for water year 2000, with an annual SSL of 74,700 tons resulting in an SSY of 705 tons $/ \mathrm{mi}^{2}$ (fig. 13). The highest SSY for water year 2002 was produced by the Blowout Creek subbasin. The road failure and debris flow upstream of the monitoring station resulted in relatively high SSY (520 tons $\left./ \mathrm{mi}^{2}\right)$ in a near average streamflow year (fig. 13). None of the monitoring stations in the North Santiam River basin recorded notably high SSY values during water years 2001, 2003, or 2004 (fig. 13). 


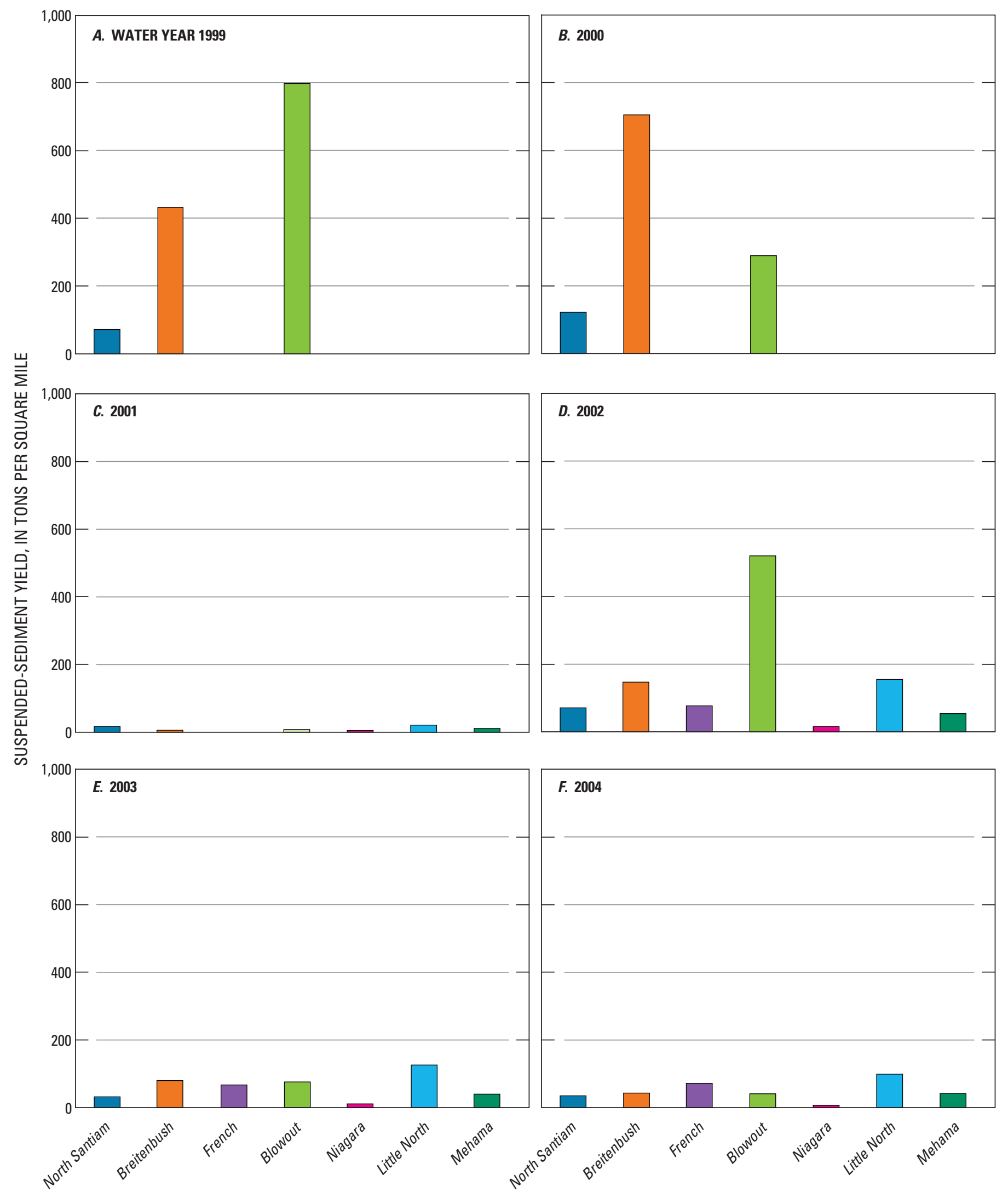

Figure 13. Suspended-sediment yield at monitoring stations in the North Santiam River basin, Oregon, water years 1999-2004. 


\section{Summary and Conclusions}

Annual suspended-sediment loads (SSL) and suspendedsediment yields (SSY) were highest during the relatively high streamflow of water years 1999 and 2000. Three-day SSL and annual SSL totals were highest in the three upper-basin stations that were in operation during one of those years. Although water year 1999 was the higher annual streamflow year, water year 2000 was the higher sediment transport year. Comparisons among the lower-basin monitoring stations were less definitive because SSL totals were available for only four water years (2001-04) that had average to below-average streamflow.

\section{North Santiam River below Boulder Creek, near Detroit}

The highest SSL totals at North Santiam were not associated with the highest instream turbidity. SSL was highest at the North Santiam monitoring station during the November 1999 storm. The 3-day SSL was more than 22,000 tons, greater than the annual SSL at the station for water years 2000-04. This storm-related SSL also resulted in the highest percentage of total annual SSL (85 percent) at this station. For the remainder of the period of study, the subbasin upstream of North Santiam produced between 29 and 50 percent of its annual SSL during the respective highest 3-day SSL. In water years 2001 and 2004, the sediment responsible for the highest SSL events originated on the slopes of Mount Jefferson, likely from glacial events or slope failures. Because these very high turbidity events did not occur in association with high streamflow, the relative SSL totals were not as significant.

The total annual SSL calculated for water years 1999 and 2000 were slightly lower than the SSL published for those years in a previous report from the study (Uhrich and Bragg, 2003). The addition of more than 20 samples to the regression analysis resulted in a change to the model-estimated SSC from instream turbidity for North Santiam. Although the $\mathrm{R}^{2}$ value was slightly lower $(0.89)$ than that of the previous model (0.91), the difference of the SSL estimates for both water years was less than 10 percent.

\section{Breitenbush River above French Creek, near Detroit}

SSL was highest at $B$ reitenbush of all stations during the period of study. The 69,800 tons of sediment transported in 3 days during the November 1999 storm represents more than twice the annual SSL totals at any of the monitoring stations for any of water years 1999-2004. The instream turbidity during this storm did not reach the sensor maximum but was higher and persisted longer than the turbidity at the other upper-basin stations. The sediment causing the high turbidity during this storm was believed to have originated in a small unnamed tributary of one main tributary of the Breitenbush River. Since this storm, the U.S. Forest Service has made efforts to reduce the amount of surface runoff in this area.
The annual SSL calculated for water years 1999 and 2000 at Breitenbush was higher than the SSL published for those years in the previous report from this study (Uhrich and Bragg, 2003). The increase was greater during water year 2000 , when the annual SSL was nearly 50 percent greater than the previous estimate. The original regression analysis included many samples with instream turbidity less than 1 Formazin Nephelometric Unit. More than 20 of these samples were excluded from the current analysis. Although many samples, including several high-turbidity samples, were added to the analysis, 10 fewer samples were used for the current model-estimated SSC from instream turbidity. The $\mathrm{R}^{2}$ value of the current model (0.92) was slightly lower than that of the previously published model $(0.95)$.

\section{French Creek near Detroit}

The total annual and highest 3-day SSL at French were nearly equal for water years 2002-04. The small subbasin (10 $\mathrm{mi}^{2}$ ) produced 765,668 , and 716 tons of sediment for water years 2002 through 2004, respectively. The highest 3-day SSL (400 tons) resulted from a small debris flow that entered the creek 0.5 mi upstream of the monitoring station during the storm on January 30-February 2, 2003.

\section{Blowout Creek near Detroit}

The Blowout Creek subbasin produced a significant SSL during storms in water years 1999-2000. The highest 3-day SSL was during the December 1998 storm. The turbidity during this event did not reach the sensor maximum $(1,370$ FNU) but was greater than that of the other two upperbasin stations. A slope failure or encroachment by the many earthflows in the subbasin may have occurred during the storm, but the SSL could not be attributed to a specific area. This storm also produced the highest SSY for any of the stations during the period of study.

The sediment source related to the December 2001 storm at Blowout was easily identifiable. Less than 3 mi upstream of the monitoring station, debris flow and a road failure carved a swath through the forest and deposited nearly 5,000 tons of sediment into a tributary of Blowout Creek. As a result of either the size of the slope failure or its close proximity to the monitoring station, the turbidity far exceeded that of the December 1998 storm. However, the higher streamflow and longer duration of the 1998 storm produced the higher 3-day SSL at Blowout.

Like at Breitenbush, the total annual SSL calculated for water years 1999 and 2000 at Blow out were higher than the loads published in the previous report from this study (Uhrich and Bragg, 2003). The current SSL estimates for both water years were 35-40 percent greater than the previous estimates. Although several turbidity samples less than 1 Formazin Nephelometric Unit were excluded from the regression analysis, many more samples were collected at Blowout. Thirty more samples were included in the current analysis, including many with high turbidity. 


\section{North Santiam River at Niagara}

The highest SSL events in the upper North Santiam River basin had minimal effect on the annual SSL at Niagara. Only 4-9 percent of the annual SSL was produced in any 3-day period during water years 2001-04. The monitoring station is located 3.5 miles downstream of Detroit Dam and 0.5 miles downstream of Big Cliff Dam. The two reservoirs function as traps for sediment transported in the upper basin, limiting sediment output downstream. Blowout Creek is the closest of the upper basin tributaries to Detroit Dam and therefore the most likely to transport sediment through the dam and downstream. In several instances, this effect could be noted when the highest SSL at Niagara closely followed the highest SSL events at Blowout.

Of the 64 suspended-sediment samples collected and used for the regression analysis at Niagara, 50 had instream turbidity less than 10 FNU. Any slight variability of SSC at low turbidity values can affect the regression model statistics. For Niagara, the $\mathrm{R}^{2}$ value of the regression model was 0.76 , the lowest of all monitoring stations.

\section{Little North Santiam River near Mehama}

The Little North Santiam River produced its highest SSL during the January 2004 storm. The 11,400 tons of sediment transported in 3 days represented 64 percent of the annual total SSL. Both the streamflow and turbidity at this station were greater than any of the other stations during this storm. The annual SSY values at Little North were the highest for all stations (126 and 99 tons per square mile, respectively) for water years 2003-04.

\section{North Santiam River at Mehama}

The turbidity and SSL at M ehama are heavily influenced by the Little North Santiam River. M ehama is located about 0.5 mile downstream of the confluence of the Little North Santiam River with the mainstem North Santiam River. As expected, the highest 3-day SSL at M ehama also was during the January 2004 storm. The 11,400 tons of sediment transported during this storm comprised only 42 percent of the annual total SSL. However, annual total SSL at M ehama was highest in water year 2002. The SSL of 35,200 tons was the second highest SSL for the period of study at any of the monitoring stations.

\section{Future Studies}

Future research will focus on fluvial sediment sources in the North Santiam River basin. Emphasis will be on identifying the geomorphic processes responsible for supplying sediment to the North Santiam River system.
Information will be collected on where the events occurred, the amount of sediment derived, the mechanism that initiated the displacement of material, and how the increase in suspended-sediment affected water quality. When possible, photographic evidence of the effects of the events will be obtained.

Suspended-clay load regression models will be developed from fluvial samples and mixtures of water and soil collected from known sediment sources throughout the North Santiam River basin. More than 500 mixtures of varying concentrations will be analyzed from such sources as earth flows, debris flows, road cuts and failures, and glacial areas. The clay loads are synonymous with persistent turbidity, which has been problematic for the city of Salem water-treatment facility to treat and eliminate.

\section{Acknowledgments}

The authors thank the city of Salem for cooperative funding, and city of Salem employees Libby Barg, Jason Pulley, Tim Sherman, and Henry Wujcik for providing valuable technical expertise and field assistance. We also thank David Klug and Doug Shank of the U.S. Forest Service, Detroit and Sweet Home Ranger Districts, for their technical leadership and field assistance. Others within the U.S. Geological Survey who assisted in the collection of samples or who contributed their considerable technical skills included Amy Brooks, Joseph Rinella, Stewart Rounds, Annett Sullivan, and John Williams.

\section{References Cited}

Anderson, C.W., 2004, Turbidity (version 2): U.S. Geological Survey Techniques of Water-Resources Investigations, book 9, chap. A6, section 6.7, accessed August 02, 2006, at http:// water.usgs.gov/owq/FieldManual/Chapter6/6.7 contents. $\underline{\mathrm{html}}$

Cooper, R.M., 2005, Estimation of peak discharges for rural, unregulated streams in western Oregon: U.S. Geological Survey Scientific Investigations Report 2005-5116, 134 p.

Edwards, T.K., and Glysson, G.D., 1999, Field methods for measurement of fluvial sediment: Techniques of WaterResources Investigations of the U.S. Geological Survey, book 3, chap. C2, 89 p.

Helsel D.R., and Hirsh R.M., 1992, Statistical methods in water resources: New York, Elsevier, 522 p. 
Hulse, D., Grant G., Niemi, E., Branscomb, A., Diethelm, D., Ulrich, R., and Whitelaw, E., 2002, Muddy waters-How floods clarify evolving relationships among landscapes processes and resource management decision-making in municipal watersheds: Eugene, University of Oregon, Department of Landscape Architecture, U.S. Environmental Protection Agency / National Science Foundation Final Project Report GAD\# R825822, 32 p.

International Organization for Standardization, 1999, Water quality - Determination of turbidity: International Organization for Standardization ISO 7027, 10 p.

Oregon Climate Service, 2005, Climate data, zone 4-Climate data archives/Daily precipitation/Detroit Dam: accessed August 1, 2006, at http://www.ocs.oregonstate.edu/index. $\underline{\text { html }}$

Uhrich, M.A., and Bragg, H.M., 2003, Monitoring instream turbidity to estimate continuous suspended-sediment sediment loads and clay-water volumes in the upper North Santiam River Basin, Oregon, 1998-2000: U.S. Geological Survey Water-Resources Investigations Report 03-4098, $43 \mathrm{p}$.

U.S. Army Corps of Engineers, 1953, Water control manual for Detroit and Big Cliff Lakes, Oregon: Portland District Report, December 18, 1953.

U.S. Environmental Protection Agency, 1999, Guidance manual for compliance with the interim enhanced surface water treatment rule-Turbidity provisions: U.S. Environmental Protection Agency, Office of Water, EPA 815-R-99-010 [variously paged].
U.S. Geological Survey, 2000, Water resources data for Oregon, Water year 1999: U.S. Geological Survey WaterData Report OR-99-1.

U.S. Geological Survey, 2001, Water resources data for Oregon, Water year 2000: U.S. Geological Survey WaterData Report OR-00-1.

U.S. Geological Survey, 2002, Water resources data for Oregon, Water year 2001: U.S. Geological Survey WaterData Report OR-01-1.

U.S. Geological Survey, 2003, Water resources data for Oregon, Water year 2002: U.S. Geological Survey WaterData Report OR-02-1.

U.S. Geological Survey, 2004, Water resources data for Oregon, Water year 2003: U.S. Geological Survey WaterData Report OR-03-1.

U.S. Geological Survey, 2005, Water resources data for Oregon, Water year 2004: U.S. Geological Survey WaterData Report OR-04-1.

Wagner, R.J., Boulger, R.W., Jr., Oblinger, C.J., and Smith, B.A., 2006, Guidelines and standard procedures for continuous water-quality monitors-Station operation, record computation, and data reporting: U.S. Geological Survey Techniques and Methods 1-D3, 51 p., 8 attachments, accessed April 10, 2006, at http://pubs.water.usgs.gov/ $\underline{\operatorname{tm} 1 \mathrm{~d} 3}$ 
Manuscript approved for publication, September 4, 2007

Prepared by the USGS Publishing Network

Bob Crist

Linda Rogers

Sharon Wahlstrom

Bobbie Jo Richey

For more information concerning the research in this report, contact the Oregon Water Science Center Director,

U.S. Geological Survey, 92130 SW 5th Ave.

Portland, OR 97201

http://or.water.usgs.gov 


$$
\frac{1}{50}
$$

